CHAPTER TWO

\title{
MAFFEO BARBERINI-URBAN VIII, THE POET-POPE, OR: THE POWER OF POETIC PROPAGANDA
}

\section{Introduction}

In the early years of the pontificate of Paul V (1605-I62I), an anonymous avvisatore assembled a series of short biographies outlining the characters and characteristics of the various cardinals who would take part in the conclave if the Pope were to die. About Maffeo Barberini he wrote, after a brief sketch of his career: 'he is a man of great talent, well versed in Italian letters, in Latin and in Greek; though more assiduous than brilliant, he is of an honourable nature, without any baseness', which was praise indeed in view of the judgement he passed on some other eminent candidates. It also shows that, already as a cardinal, Barberini was known as a writer, a poet. ${ }^{1}$

Some twenty years later, when Maffeo had become Urban, the wellknown literato Fulvio Testi described to a friend an evening he had spent with the Pope. Apologizing to Urban for not having written any poetry recently due to his increased work load, Testi was gently reprimanded when the Pope remarked: 'We, too, have some business to attend to, but nevertheless for Our recreation sometimes We compose a poem'. Urban went on to tell that he had lately written some Latin poems and would like Testi to read them. And hence, retreating into the next room where he sleeps, he fetched some sheets and started to read to me an ode written after the manner of Horace, which really was very beautiful. I have lauded it and praised it to the stars because certainly as to Latin compositions the Pope has few or none who equal him. ${ }^{\prime 2}$

\footnotetext{
${ }^{1}$ Biblioteca Apostolica Vaticana (BAV), Manoscritti Boncompagni-Ludovisi, Vol. C 20, f. I67: "è signore d'ingegno grande, di belle lettere vulgari, latine e greche, e piutosto assegnato che splendido, ma honorato, senza sordidezza".

${ }_{2}$ M.L. Doglio, ed., F. Testi. Le Lettere, II. I634-I637 (Bari I967), 373-374: "E noi pure abbiamo qualche negozio e con tutto ciò per nostra ricreazione facciamo alle volte qualche componimento" (...) "e cosi tirandosi nell'altra camera, dove dorme, ha dato di piglio a un foglio, e m'ha letto un'ode fatta a imitazione d'Orazio, che veramente
} 
However, in I643, the praise that, for yet another twenty years, had been bestowed on the poems of Pope Urban VIII came to a sudden end. Obviously, the Barberini's disgrace which marked the first year after Urban's death made people wary to continue lauding the late pope's poetry. Publishers also must have thought twice before deciding to run a new edition; understandably, they rather tried to curry favour with the new Pope, Innocent X (1644-1655), who was known to be less than interested in such forms of culture and, moreover, positively hated his predecessor. While Innocent's successor, Alexander VII (I655I667), was, again, a great patron of the arts, he nevertheless was too self-centred, not to say vain, to encourage initiatives that would ensure the reputation of Pope Urban as a poet; he rather sought to make his own mark than propagate the fame of the Barberini pope. Also, the taste of the times had changed. Hence, a critical evaluation of Urban's poems, not hampered by the pope's powerful presence, did not arise. The I8th century saw a few new editions of his works, amongst which, surprisingly, a full-blown Oxford one. The igth century remained silent on this aspect of Urban's biography and of its bearing on papal cultural policy, partly because it did not conceive of the papacy in terms of a cultural agency with obvious propagandistic aims and partly because of its new appreciation of the poet as the romantic genius. Only the great chronicler of the popes, Ludwig von Pastor, dealt with Urban's efforts in this field. ${ }^{3}$ After him, there was silence again, till the 1970's saw a faint glimmer of renewed interest.

\section{A poetic program? "Levan di terra al Ciel nostr'intelletto"- 'they lift our understanding towards Heaven"4}

Poetry may well have been Maffeo Barberini's first and most important inclination. Therefore, it is amazing that at least as far as I know no one has ever thought of analysing Maffeo's life's achievements in terms of what obviously were his life's greatest joy, his poems. Admittedly, it would be stretching the available evidence too far if I were to suggest

\footnotetext{
è bellissima. Io l'ho lodata et esaltata fino alle stelle perche certo nei componimenti Latini il Papa ha pochi o nissun che l'aguagli."

${ }^{3}$ L. von Pastor, Geschichte der Päpste, XIII-2 (Freiburg I928), 900-909.

4 This is the motto of: G.F. Ferranti, ed., Poesie latine del cardinale Maffeo Barberini hoggi papa Urbano ottavo (Rome I642).
} 
there exists some kind of hermetically worded poetic program that, if disclosed, would give us a key to all of Maffeo's actions. Nevertheless, Maffeo's poetic compositions, both the ones written before his pontificate and the ones composed after his election, offer important clues to his thinking. It seems to me they can and should be read as a running commentary on many of the issues he had to confront, on many of the actions he did take; they even seem to suggest a unity of thought that may help to give meaning to a number of his deeds and, moreover, point to a surprising consistency and continuity in his policy.

However, as most of the poems are difficult to date exactly - neither the manuscript nor the printed sources allow this - some of the suggestions made hereafter cannot but be tentative. ${ }^{5}$ Still, as collections of Cardinal Barberini's poetry were published even before he was elected to the papacy, we can at least date most of the poems to either before or after I623. ${ }^{6}$ Thus, we can try to determine which ideas had germinated before this decisive moment in Maffeo's life and career and which ones were written later, under the pressure of drastically changed circumstances and, therefore, outlooks.

\section{Maffeo's early poetry: from the dangers of life's pleasures and the obligations of family "pietas" to the glorification of Divine Wisdom}

Although this chapter does not aim to offer a potted biography, some data on the early life of the man who became Pope Urban VIII have to be provided first.

Maffeo Barberini was born on April 5, 1568 as the youngest of the six sons of Antonio Barberini and Camilla Barbadori, who were citizens of Florence. Young Maffeo was first sent to school with the Florentine Jesuits and then, in 5584 , moved to Rome to live under the tutelage of

${ }^{5}$ A valuable effort has been made by: M. Castagnetti, 'I "Poemata" e le "Poesie Toscane" di Maffeo Barberini. I. Stampe e problemi di cronologia', in: Atti e Memorie dell'Accademia Patavina di Scienze, Lettere et Arti, Series IV, XXXIX (1979/I980), 283-388. Yet, her lists (318-388) are both incomplete and, to a large extent, approximate, only.

${ }_{6}^{6}$ According to M. Costanzo, Critica e Poetica del Primo Seicento. Vol. II: Maffeo e Francesco Barberini, Cesarini, Pallavicino (Rome 197I), between I620 and I643 some I5 authorized collections of Maffeo's Latin poems were published, whereas of the Italian verses only 5 editions appeared, between I6 35 and I642. My own counting differs from Castagnetti's - as in note 5, supra - and Costanzo's. In Appendix I, a list of the editions is given of the collections I have been able to trace. Besides the manuscript texts, they form the basis of this chapter. 
his uncle Francesco. In Rome, too, he was schooled in the humanistic curriculum of the Jesuits, in their famous Collegio Romano. Despite his obvious cultural interests, the career mapped out for a young man of his social background demanded that he go on to university to study for a law degree. This he did, at Pisa, where he spent several years. Though he wanted to marry, nothing came of the match arranged for him by his mother. Therefore he returned to Rome in 1588 , to seek a career in the Church. With the initial aid of his uncle he soon succeeded, gaining one position after the other and thus moving upwards in the hierarchy of the Curia. The life he had started in 1588 found its culmination in I623, with his election to the papacy.

Since most of Maffeo's published poems are not dated, and the manuscript texts, preserved in the Vatican Library's Barberini Latini, give little information as well, it is somewhat difficult to determine when young Maffeo first embarked on his poetical career. Obviously, the writing of poetry was part of the accomplishments of a gentlemanscholar and therefore incorporated in the educational curriculum of the elite. In his youth, the main influences on Italian poetry still were the sonnets of Petrarch. Recently, some i3 Italian sonnets of young Barberini have been published, all, apparently, written between 1580 and $1600,{ }^{7}$ i.e. from the age of twelve onwards. These so-called Tuscan poems, especially in the form of these early sonnets, are visibly less formal, rather more eclectic and, indeed, sometimes more gallant than Maffeo's later Latin poetry. ${ }^{8}$ It is not clear whether Maffeo ever planned to publish these early exercises, although his biographer Nicoletti seems to suggest there existed a project to do so in $1617 .{ }^{9}$ In the end, the first edition of the Pope's opere volgari appeared only in I635. However, since, of course, it would not do for a Roman pontiff to have his early, however chastely-worded explorations of the land of the senses publicly revealed, the poems praising female beauty and the love generated by the desired object were suppressed.

Reading the manuscript poems, it is obvious that some of them have a thematic unity of their own, addressing life's major moments and problems in describing Man's experiences between the poles of birth

\footnotetext{
${ }^{7}$ Costanzo, o.c. The manuscripts of these poems are preserved in: $B A V, B L$, Vol. 4009 .

${ }^{8}$ Costanzo, o.c., I5-35.

${ }^{9} B A V, B L$, Vol. 4730 , the Vita by Nicoletti.
} 
and death, the experiences of sensual love and hope of fame, but, also, of conversion, and of mystical elevation. Already, they give us a glimpse of the development of Maffeo's ideas.

Specifically the sonnet-cycle, if it can so be called, in describing Man's life as he is led astray by the pleasures of the world presented its various topics moralistically: the reader is admonished to withstand the world's seductions and take the path to virtue, which shall be obtained in Heaven. In the I $3^{\text {th }}$ sonnet, about the sacred stigmata of St. Francis of Assisi, Maffeo addresses Man's soul, writing: 'Though now you may be denuded, you will be rich in Heaven'. ${ }^{10}$ Significantly, the theme of poverty, which would be recurring over the following decades, is prominent already. Stylistically, these poems do show the general influence of Petrarch and, more specifically, of Giovanni Battista Marino ( $1569-$ I625), in their mostly moderate but sometimes also extreme lyricism. Still, this juvenile dossier of Maffeo's, which antedates even his early years as a young prelate, shows genuine feeling, never assuming the fulsome rhetoric of the time. Nor does it display his later, more Baroque tendency to use intricate parallels and antitheses, to create complex concetti.

Besides these poems, only recently published, many others remain unread in the Barberini manuscripts. Some of them show the aspiring poet at work in the I580's, in the milieu of such late I6th-century poets as Giovanni Aleandro (I574-I649), Aurelio Orsi and Giovanni Battista Strozzi, who moved in the more exalted circles of Curial culture. Obviously, The young prelate - not a priest, yet! - sought to improve on first thoughts and elaborate his ideas in engaging in discussion with, precisely, such more established authors as Orsi. ${ }^{11}$

Among Maffeo's late-juvenile efforts is a poem praising the eyes of a certain young lady of the Florentine family of Del Nero, as well as an entire cycle devoted to "Portia", but also an ode to the Arno, the river of his home town, and a text addressed to Pietro Aldobrandini, the Cardinal-Nephew of the reigning pope, Clement VIII, who is advised to support his uncle and, in his stead, rule the world - a first indication of Barberini's views on nepotism. ${ }^{12}$

\footnotetext{
10 Costanzo, o.c., sonnet I3: "S'or nuda sei, nel Ciel ricca sarai."

${ }^{11} B A V, B L$, Vol. 40og, f. I8 $8^{\text {r }}$ sqq.

$12 B A V, B L$, Vol. 3757 , fols $\mathrm{I}^{\mathrm{r}}-55^{\mathrm{r}}$. Some of these also can be found in $B A V, B L$, Vol. ı19, which has other juvenilia as well.
} 


\section{The intermediate years: professional and poetic developments}

Though Maffeo constantly complained his many tasks kept him from his favourite pastime, yet even while in residence at his see of Spoleto, or, later, as prefect of the Segnatura della Giustizia, he continued to write poetry - now starting to compose Latin verses as well - and to discuss it with others, both eliciting their comments and commenting on their own efforts. Thus, he argues about the effect of repetition, analyses the function of specific sounds, and accepts proposals for alternative wordings in his odes. ${ }^{13}$

Maffeo's Latin verses were part of a poetic movement that characterised the beginning of the 17 th century. It was a poetry that hoped to effect moral restoration: its main aim was didactic. In the choice of his topics, the young prelate proposed ideals he often took from the world of the early Christians who he held up as examples to its readers. His poetry affected a sober style, of a somewhat biblical bent, stressing the epic and, indeed, tragic aspects of its subject matter. While stylistically the verses of the early izth century grew out of the Marinism of Maffeo's early years, it increasingly rejected its complex sensuality. It finally reached a moderate Baroque style, characterised by such epithets as grand and sublime, proportionate and yet splendid.

In achieving this new style, Maffeo was clearly influenced by the men he met as he moved up the ladder of the curial hierarchy, which was the ladder of worldly success as well. Now, his poetic inclinations automatically brought him the friendship - if rivals ever can be friends - of his (younger) contemporaries such as Virginio Cesarini $\left(\mathrm{I}_{595}-\mathrm{I} 624\right)^{14}$ and Giovanni Ciampoli ( $1589-\mathrm{I} 643$ ), who dominated the Roman literary scene. They all were affected by the work of Gabriele Chiabrera (I552I637), the main exponent of the Baroque style of Italian poetry whom Maffeo honoured with laudatory poems and with whom he maintained a correspondence. ${ }^{15}$

Indeed, Maffeo's poems seem specifically indebted to the classical ideals of Chiabrera though I feel that Chiabrera's rather bloodless use

\footnotetext{
${ }^{13}$ E.g. the many letters in: $B A V, B L$, Vol. 2047.

14 There seems to be no contemporary study of his works. See, hoewever, his poems in: Septem virorum illustrium poemata (Amsterdam I672).

${ }_{15}$ Cfr. G. Getto, Barocco in Prosa e in Poesia (Milan I969), 405-476 for the background. The poems are in: Maffeo Barberini, Poemata (Paris I642), I3I-I32; I42; I79-180; I8II82.
} 
of Christian heroes clothed in classical garb lacks the religious fire Barberini proved capable of instilling in his better poetry.

Chiabrera, a client of the ducal house of Savoy, liked to take such saints as Mary Magdalene and Sebastian as the focal point of his heroic-moralistic poems, as, for example, in the ones he dedicated to Christina of Loraine in 1598. His experiments with Greek metre influenced Maffeo as well. ${ }^{16}$ In I6I4-I6I5, we find him commenting on Maffeo's poems. His criticism was mild, understandably, perhaps, since, by that time, Maffeo already was one of the more influential cardinals of the Curia, whose patronage now was sought by Chiabrera himself: such were the reversals of fortune and position that could be the effect of power in the field of high culture. No wonder Chiabrera wrote an ode for him, using, as so many were to do for the next thirty years, the panegyric theme of the Barberini bees. ${ }^{17}$

Yet, though Maffeo generally took his clues from the Pindaric odes favoured by Chiabrera, his metre was rather more Horatian. Still, in Chiabrera's wake, his poetry developed along dithyrambic lines, using sometimes overwrought hyperbole and rhythm to create the desired emotional tension, a 'sweet disorder', to use the characteristic of this genre of poetry given by Mario Praz. ${ }^{18}$ But whereas Chiabrera's poems sometimes verged on the excessive in their stylistic choices, Maffeo's by and large remained moderate.

An important aspect of Maffeo's poetry becomes evident in the poems he dedicated to or rather directed at various members of his family, revealing what kind of ideals he tried to impose upon them. In a sense, they were both his material and his readership. Most of these poems probably date from the period of his cardinalate when he was considered the family's actual head. Precisely because Maffeo was the Barberini's 'spiritual guide' as well as their most prominent social and political representative, some of the poems of this 'intermediate period' are of specific importance in determining what was the nature of his 'nepotism' before I study the phenomenon in its final, papal context, so often interpreted purely negatively. Moreover, in analysing Maffeo's influence on his nephew Francesco, whom he raised and who was to be his closest and most powerful collaborator during the twenty-odd years

\footnotetext{
${ }^{16}$ G. Jannacao, M. Capucci, Storia Letteraria d'Italia. Vol. V. Il Seicento (Milan I986), 234

${ }^{17} B A V, B L$, Vol. 6462 , fols. $\mathrm{I}^{\mathrm{r}-\mathrm{I}} 4^{\mathrm{v}}$ hold the Chiabrera-Barberini correspondence.

18 M. Praz, Mnemosyne. The Parallel between Literature and the Visual Arts (Princeton 1974).
} sqq. 
of his papal reign and shaped papal cultural policies as much as his uncle did, ${ }^{19}$ I feel we can actually also get to know the man behind the Pope.

In a piece titled Trias inclyta fratrum, Maffeo outlined the different ways taken by each of the three Barberini brothers of his own generation who had moved to Rome: with Antonio pursuing a life of poverty following in the footsteps of Christ, and Carlo, who had married, raising and educating his children, he himself is obeying the call of his vocation, cultivating his career in the Church. Nevertheless, Maffeo is fully aware of the lure of worldly glory. In his Sonnets 25, 26 and $46^{20}$ he admonishes himself to battle against vanity, and to accept that rather than being their own fulfilment with the fame they bring, his poems should be seen as the key to Heaven, through an understanding of Heaven's intentions.

Meanwhile, just as his own uncle had advanced his career, Maffeo, too, had decided at least one of his kin in the next generation should directly profit from his growing power and success. The moral obligation of pietas was, after all, to be directed first and foremost to one's own relatives. In I6I 4 we find young Francesco, one of Carlo's sons, studying at his uncle's old school, the Collegio Romano. Lessons are, apparently, quite strenuous, and the young man shows his worries in a letter to Uncle Maffeo. ${ }^{21} \mathrm{He}$ is sent a long poem, mapping the path he will have to take. In order to better interpret this Ode hortatoria ad virtutem, one should turn to a contemporary letter written by Maffeo to his brother, the Capuchin friar Antonio. In this poem, for the first time he explained the principles that guided his poetry and, indeed, become evident in the composition of the long ode for Francesco and of another one, composed for Antonio himself. ${ }^{22} \mathrm{He}$ states it is his aim to christianize the mythological themes that prevail in contemporary culture, and thus steer the readers from the profane to the sacred, from the temptations and worries of the World to the consolation of Heavenly Wisdom. With many classical references, mainly to Greek mythology, the Exhortatio ad virtutem as it is also called charts the path of life for the young student, calling upon him to become acquainted with music and poetry

19 See chapter III of this book.

20 Poesie Toscane (Rome i635).

21 Francesco to Maffeo as quoted in: Costanzo, o.c., I I3.

${ }_{22}$ Maffeo to Antonio, i2 April i6r4, as cited in: Costanzo, o.c., iri. The ode for Antonio is in: BAV, BL, Vol. I0o88, fols. 6I-62. See also: Poemata (Paris I623), 42-43. 
as the means to spread Divine Wisdom, thus following the course Maffeo is taking himself. Yet, Francesco should be aware of the snares of 'lust, which speaks with a charming tongue'. Like Ulysses, he should withstand the sirens. Like Theseus, he should hold to the thread of Ariadne. In taking the steep path of virtue, he will finally see Heaven and shine like a new star. ${ }^{23}$

In the ode addressed to his brother Antonio - 'the most loved one', viz. of all his brothers: the other ones always have to do without this epithet! - Maffeo stresses the virtue of poverty, admonishing Antonio to trace the steps of St. Francis, and adopt those religious ideals of which the bare feet are the outward sign. Yet, he realizes that his own mission forces him to follow a different course. Another poem probably composed before Maffeo's accession to the papacy, is addressed at his brother Carlo, instructing him on his role as father and educator - of young Francesco, among others. Three vices should be avoided at any cost: avarice, lust and pride. ${ }^{24}$

Two other poems of uncertain but probably later date indicate the roles Maffeo planned for Carlo's two other sons, young Antonio and Taddeo. They seem to continue the ideal he had adopted a few years before.

Antonio, who later entered the priesthood, was admonished to study and develop his poetical qualities, as these were highly suitable to man of the Church: the text that went with the emblem which was attached to this poem in a later edition read 'there is sweet knowledge in honey and the muse', meaning, of course, in the virtue that came from the bee - and, hence, from the Barberini? - as a messenger of Divine Wisdom and in poetry as its expression. However, though Antonio did become a great patron of the arts, especially of music, his life turned out rather less exemplary than must have been pleasing to his papal uncle - he was know to have a long-standing affair with his castratolover.

Taddeo, who was destined for a career in the world, was told that the ways of that world inevitably were the ways of vice but that it was possible to proceed towards virtue and, thus, to reach God. In the above mentioned edition of Maffeo's poems, the caption of the emblem adorning this piece read: 'though the bee is small, it can inflict big wounds', meaning, obviously, that Divine Wisdom did not

23 Poemata (Paris I623), 35-39.

24 Poemata (Paris I623), 45. 
need an entire army to reach its goal - which reminds one of the stupidity of Stalin's famous question 'how many divisions does the pope command?' Alas, the papacy did have to rely on its secular arm, sometimes, but Taddeo, who was made General of Holy Church, proved rather unsatisfactory as a military man.

A 2oth-century observer would feel Maffeo opens his mind rather more clearly in a letter he wrote to one of his nieces, Camilla, Carlo's daughter. When she asked him to counsel her on her plans to take the veil, he took pains to cover two sheets with advice that sounds thoroughly modern, showing insight into the psychology of a young girl raised in the probably rather strict confines of a Florentine patrician family. He tells her that to really know whether she has the calling, she should spend considerable time in searching her own mind, trying to know her deepest wishes as well as her strengths and her weaknesses. Especially in the young, the voice of vocation can be deceptive, Maffeo suggests, and moreover one does not always know one's own motives in following it. Also, if one has made up one's mind, one should be careful in selecting the right establishment. It has to be a nunnery with a definite, strict rule - we hear an echo of Maffeo's wish for discipline according to the Church's old traditions - but one should not engage upon a way of life that one could not sustain. Camilla would do well to consult her Capuchin uncle Antonio - another instance of the reverence with which Maffeo always treated his brother, whose worldrenouncing way of life he openly admired, and envied. Concluding, Maffeo argues that it is essential Camilla should be aware of her own, complete freedom in this matter - he even seems to intimate that her parents' wishes, if such there are, should not prevail. If, however, she decides to go through with her plan, Maffeo will give her the dowry that will allow her to enter the monastery of her choice. ${ }^{25}$

It is important to note that in all these cases of poetic exhortationthere are moralistic exhortations addressed to his brothers Alessandro, Giovanni Donato and Nicolò as well ${ }^{26}$ —we find Maffeo Barberini outlining a way of life, a system of ethics that he wanted both himself and his relatives to adhere to. It is important, too, to note that this was in I6I4 or thereabouts, long before he could have dreamt of attaining

\footnotetext{
25 BAV, BL., Vol. 4729, fols. 625 ${ }^{\mathrm{r}}-626^{\mathrm{r}}$, Maffeo to Camilla, 6 April i6 I3.

${ }^{26}$ Maffeo Barberini, Poemata, 96-97; 98-Ioo; II2-II5, on the following topics: "Qua ratione pravus animi affectus fugiendus, et curandus"; "Inanis eruditio sine pietate"; and: "Militia est vita hominis super terram".
} 
the highest position within the Church and sharing it with his relatives, according to contemporary ideas about family pietas and, hence, nepotism. ${ }^{27}$ In these years, though Maffeo Barberini, in a way, gave word to ideals that were part of the customary culture of a man of his background, education and status in Roman society, both the sustained quantity and the quality of his poetry, his chosen means of expression, were far from usual. Moreover, his poems also embody the changes that were working in that culture, that was moving away from the 'pagan' Classicism of the Renaissance to the post-Tridentine ideals of the Baroque.

\section{The last phase: the apogee of papal poetry}

The first period of Maffeo's poetry, spanning the years of his youth till approximately I60o, the year which marked the beginning of his career as a high-ranking prelate, can be characterised as rather conventional in its emphasis on Man's need to lead a virtuous life, while at the same time it shows the usual encomiastic tendencies of a man who operates in a court society. The second period, while continuing in this vein, shows a more obvious predilection for religious themes presented in a moralistic manner. This period stretches well into the first years of the papacy, but in the later I620's another change becomes noticeable.

Almost compulsively, Maffeo, now Pope Urban, takes every opportunity to use his poetic qualities to further the cause of the Church and, in it, the position of the Roman primate. Consequently, in its thematic choices his poetry acquires a decidedly political quality that it lacked in the earlier periods.

Thus, the great poem on the Countess Matilda of Tuscany (IO46II I4), probably coinciding with Urban's decision to ask Bernini to begin her monument in St. Peter's, in I633, stresses the territorial integrity of the Papal States which, of course, had grown from her bequest of her extensive lands in Central Italy to the Church and its ruler. Indeed, in the years following I63I, Urban had ordered the restoration and the extension of the famous "Galleria delle Carte Geografiche", with the huge frescoed maps of the world, in the Vatican Palace, to show

27 This point seems to me to have been overlooked by Scott, o.c., who bases a not unimportant part of his analysis of the decoration of the Barberini Palace on a papalnepotistic interpretation precisely of the ode for young Francesco. 
the visitors from all over Christendom the position of the papacy in (Christian) Europe and the role that Christian Europe should play in the world.

From 1633/i634 dates the poetic call for a new Holy War against the infidel Turks, which would have restored the papacy to its ancient role as the leader of Christendom. It coincides, probably not incidentally, with the dedication of the canopy over St Peter's tomb in the Vatican basilica, exactly I333 years after the dedication of old St Peter's by Pope Sylvester. Bernini's grand baldachin, with its helical columns, was meant to symbolize a 'machine', a road that moved one to Heaven. Admittedly, the Pope himself had written: 'Nec Turri Babyloniae nec Montibus gigantibus, sed Scala Iacobi, et Caroli Borromaei Vestigiis et Bellarmini Gradibus Coelum peti...', ${ }^{28}$ as if to indicate that, rather than create great monuments, people should take the two great Tridentine saints-scholars as their examples. Yet, he had taken the bronze from the Pantheon - the temple dedicated to 'all the gods' - to raise a monument in the temple dedicated to the One, True God. It was an absolutely meaningful act, the more so as, of course, this temple, in the Vatican, with this canopy, were the 'copies' of the ones in Jerusalem - the church of the Holy Sepulchre, with its canopy over the main altar-, just as Rome was the 'second' Jerusalem. To recapture that first Jerusalem, now ruled by the Infidel, was one of Urban's great projects. ${ }^{29}$

The tone of Barberini's later poems changed as well. Increasingly, it seems the Pope felt that good poetry was, indeed, always, moral poetry. Maffeo strongly believed that the contemplation of nature should and would lead to God, whereas such things as human beauty only could induce false and even impure thoughts. True, Man had these thoughts but they should be tamed-addressing his nephew, Taddeo, Maffeo wrote: "Il cuor uman, Taddeo, rassembra un mare": 'Man's soul is like the sea', ${ }^{30}$ tempestuous, always changing, unreliable.

There was, indeed, an ethical-Aristotelian touch to Maffeo's thinking, which one even 'feels' looking at him as he appears as one of the courtiers in Caravaggio's portrait of the fameglia of Cardinal Francesco

\footnotetext{
28 Poemata, edition Rome i635, 247.

${ }^{29}$ Cfr. also the poem on the dedication of the canopy by one of Urban's learned courtiers, Lelio Guidiccioni, Ara Maxima Vaticana (Rome I633); the manuscript copy is in: BAV, Ottob. Lat., Vol. 2420.

30 Poesie toscane (Rome I635), sonnet 45.
} 
del Monte. Yet, there were other strains in Maffeo's poems, as indicated above. Some of them derived from the encomiastic tradition of Renaissance and Baroque poetry largo sensu: they show a need to participate in the great events of the day, which, however, he interprets from the point of view of Rome, of the Church's interests and, after his accession to the papacy, of his own position in that universal constellation. As such, they deviate from the poetic ideals formulated by a lyrical poet like Marini, notwithstanding the fact that, in his early years, Maffeo used to admire his work. Yet, here, too, the Aristotelian influence is noticeable. For did not Aristotle, in his 'Poetics', claim that poetry, besides dealing with traditional myths, should also cull its themes from real life?

Obviously, Maffeo, as many of his contemporaries, was part of a tradition initiated by St. Thomas Aquinas who had tried to make Aristotle's Poetika the basis of the poetry of the Church and of the Christian world. Aquinas having failed to finish his translation and edition of Aristotle, the influence of the Poetika on the Christian figurative arts had remained limited till Lorenzo Valla's I498-edition reintroduced it. ${ }^{31}$

Already in the early years of the i7th century, Maffeo, indeed, seems to have adopted a mildly pro-Aristotelian, anti-Platonic stance in insisting that poetry, instead of inducing passions, was meant to lead to a catharsis, and, thus, to create virtue. As Aristotle argued, contemplating creation, it should rise above the insignificant, the facts, in short above history, or rather: it should signify it and thus reach an understanding of the universal truth, the essential unity of things. In poetry, as in every art, imitation, through rhythm and harmony, will lead to knowledge. ${ }^{32}$ Poetry will unite the "mythos", creative fantasy, and the "logos", the underlying concept. But to fulfil their function, poems have to be transparent, readable; they have to bring the reader towards an understanding of the final harmony of creation, in short: of God.

Maffeo's poems show that, following Thomas, he, too tries to transform the non-theological essence of Aristotle's views into a theo-anthropocentric concept: Man's ethical and intellectual need of God was to be realised through the observation of beauty, through the creation of art, of poetry, which should be an instrument to teach the mind both through contemplation and through the intellect. However, for all the

${ }^{31}$ Cfr. for some of the earlier developments: E. Simi Varanelli, 'La riscoperta medievale della poetica di Aristotele e la sua suggestione sulle arti figurative tardoduecentesche', in: A.M. Romanini, ed., Roma, anno I30o (Rome I983), 833-86o.

32 Aristotle, Poetika, 4, I I48, b7-8. 
neo-Aristotelian roots of this poetics, it is not impossible to discern some neo-Platonic influences as well, for Maffeo obviously hoped that somehow a 'divine furor' would help the readers of his poetry to be imbued with God's spirit.

Meanwhile, though it is obvious that Maffeo's Latin poems were part of a more general current in Italian poetry, his increasingly exclusive devotion to biblical and other religious themes presented as moral lessons set him apart from the mainstream. Nevertheless, he definitely seems to have influenced some of the men in his entourage, though, of course, one should bear in mind that his growing importance and power made him a person whose protection was sought and one whom, therefore, it may have been profitable to follow. Indeed, some of Maffeo's friends who, when he was crowned with the tiara, became his courtiers, were prolific poets as well, though most of their work was never published. ${ }^{33}$

One of them was Virginio Cesarini who, as mentioned above, already in the I6ı admonished the then Cardinal Barberini to use his poetry for its eminent, didactic purpose. It should have a central role in education, and be the instrument par excellence to divulge the contents of laws and science. ${ }^{34}$ Another friend-courtier was Giovanni Ciampoli, who later became the papal poet laureate. He hailed Urban as the 'sacred hero', the 'new Pindar'; already during Maffeo's cardinalate, he admonished him to use his position as a member of the 'Senate of Christendom' to make poetry an instrument for the improvement of society. ${ }^{35}$ The image is, of course, interesting: papal Rome had succeeded imperial Rome, and the cardinals had taken the place of the one-time senators - as the pope, by right, now was the 'divine emperor', the priest-king... Regrettably, Ciampoli's own works were not immortalised in printed editions, either separately or collectively. One of the reasons was that in the wake of Galilei's fall from papal favour in the early i63o's, he, by then secretary of the Papal Briefs, also lost his position, since he had been and continued to be one of the Florentine scholar's admirers. However, one still can enjoy Ciampoli's poems, viz. as part of the great musical production of the various Bar-

33 G. Costanzo, Critica e Poesia del primo Seicento, I. Gli inediti di Giovanni Ciampoli (I59oI643) (Rome I969).

34 Some of the letters of Cesarini to Maffeo Barberini are in: $B A V, B L, 2$ I89, fols. I ${ }^{\mathrm{r}}-$ $3^{\mathrm{v}}$.

$35 B A V, B L$, Vol. 3777 , fols. I8 ${ }^{\mathrm{r}}-24^{\mathrm{r}}$, and: Vol. 2 I 89, f. $4^{\mathrm{v}}$. 
berini courts: Giovanni produced the texts for much of the compositions that honoured the many grand moments of Urban's pontificate and of the lives of the various members of the Barberini family-his poem 'Five Swans on the Coronation Day of Pope Urban VIII', set to music for alto, bass, tenor and orchestra was sung in the Sistine Chapel. ${ }^{36}$ In his manuscript poems, ${ }^{37}$ and even more in his extensive dialogue on the relationship between poetry and devotion, ${ }^{38}$ we find many themes dear to Urban - whether they reflect Ciampoli's need to humour his papal patron or, conversely, they were instrumental in shaping Urban's own work is difficult to determine. Nor should one underestimate the possibility of shared ideals: Ciampoli already wrote verses that showed an understanding of Maffeo's feelings while the latter was still 'only' a cardinal. ${ }^{39}$

\section{The first collected edition}

On March II, I62I, the Divinity School of the Sorbonne permitted a Parisian publisher to print the poems of Maffeo, Cardinal Barberini, onetime papal nuncio to France. Actually, the School's censors told the reader that, in this specific case, permission was, of course, superfluous. Yet, it was the first ever collected edition of the poems of Maffeo Barberini though, in fact, based on a 'pirate' edition that, while not officially authorized by Maffeo, had been published in 1620 at the instigation of the Cardinal's admirer, the Provençal nobleman Nicholas Fabri de Peiresc. Nor had it failed to elicit comments of other French admirers. ${ }^{40}$

It all had begun when, in i6 8 , Maffeo had sent one of his 'compositions' to his friend Girolamo Aleandro, a learned Humanist frequenting the papal court, asking him to forward it to Peiresc, whose fame among the "litterati" of Europe was great but whom he did not personally know. The ode was in honour of St. Mary Magdalene, the patron saint of Peiresc's beloved Provence. The poem, that, perhaps, had been

\footnotetext{
36 BAV, BL, Vol. 3777 , fols. $135^{\mathrm{r}-\mathrm{I}} 47^{\mathrm{v}}$.

37 Many of Ciampoli's poems are in: BAV, BL, Vols. 3647, 3671, 3709, 3710, 3777, 3790, 3786, 3875, 3886, 4003.

${ }_{38} B A V, B L$, Vol. 4 oo 3 , fols. $676^{\mathrm{r}}-770^{\mathrm{v}}$.

${ }^{39}$ E.g. $B A V$, Vat. Lat., Vol. 8658 , nr. 6, "Se fra scetri e tesori".

${ }^{40}$ E.g. the letter in: $B A V, B L$, Vol. 2047, f. $59^{\mathrm{r}}$, of a patrician of Toulon.
} 
written as early as i6II, clearly reflected Barberini's deep-felt emotional relationship to the spirit of her penance.

Delighted by the honour, Peiresc did not hesitate to circulate the poem amongst his Parisian acquaintances. He soon wrote his first letter to Maffeo, telling him of the poem's success both at court and among the scholars of the Sorbonne. Indeed, he had felt free to publish it at his own expense, albeit without giving the author's name. The printed poem also was distributed in Provence and affixed to the saint's painted and sculpted images in various chapels and shrines. ${ }^{41}$ Apparently, and, in view of his obvious vanity not surprisingly, Barberini was charmed with Peiresc's gesture. Soon, a correspondence developed, mainly concentrating on the topic of Maffeo's fervent wish to acquire a considerable portion of the saint's relics to sanctify the chapel he had erected for his family in the Roman church of Sant'Andrea della Valle. ${ }^{42}$ In a third letter, Peiresc expressed his willingness to oblige, even reporting he had approached King Louis XIII himself, at St. Germain, to ask him for the necessary orders.

Meanwhile, Cardinal Barberini, as by now he was, also had an eye for the contemporary political situation. Still, this does not necessarily mean that his two great odes of I6rg and $1620,{ }^{43}$ the one on San Lorenzo, of Spain, and the other on Saint Louis IX, of France, do not also reveal his reverence for these two men and, more specifically, their virtues: e.g., Saint Louis's crusade, while, in a certain sense, a topos, did manage to stir heroic-religious feelings in more than one contemporary breast. The two odes can be dated on the basis of the correspondence between Maffeo and his secretary Francesco Bracciolini-who, incidentally, had written a gigantic poem on the retrieval of the Cross as an allegory on the Church's policy towards the Islamic East, on which Maffeo commented in his own hand. ${ }^{44}$ A prolific poet in his own right, Bracciolini's career developed from a position as young Barberini's free and even somewhat patronizing stylistic adviser in the late I590's to that of sycophantic collaborator of the powerful cardinal. It reveals, even in the wording of the letters, some of the tragedy of the 'client' in the system of patronage. Bracciolini's tone slowly alters till, in his last letter, he needs to humbly offer his service to the young nephew of his former

\footnotetext{
$41 B A V, B L$, Vol. 6502, f. I $^{\mathrm{r}}$, Peiresc to Barberini, November 2 I, I6 18.

42 See the Prologue to this book.

43 BAV, BL, Vol. 4022, fols. $98^{\mathrm{r}}$, $105^{\mathrm{r}}$.

$44 B A V, B L$, Vol. 3983 , fols. $\mathrm{I}^{\mathrm{r}}-436^{\mathrm{v}}$.
} 
master who has just been elected to the papacy and to whom, for that reason only, he cannot now directly write anymore..$^{45}$

While the same was to happen to Peiresc, yet he managed to retain a far more independent position. After the initial epistolary exchanges with Cardinal Barberini, the tone of his letters changed, with Peiresc assuming the role in which he was to continue for the next twenty years, viz. acting as a self-appointed adviser to Maffeo in matters of scholarship and general learned culture, and using this precious contact to further the career of men known to him.

This showed when Peiresc suggested that, perhaps, Barberini might compose an ode in honour of Saint Louis, which would greatly please the present king who is, of course, the thirteenth of that name. Barberini immediately indicated he would not mind doing so at all. Asking Peiresc for material to base his text on, he was advised to read the life of Louis IX by his contemporary Joinville. ${ }^{46}$ In I619, Barberini's Ode to Saint Louis was published in Paris. It was then that Peiresc asked permission to publish Barberini's entire oeuvre to date. ${ }^{47}$ In I620, this enterprise matured. Barberini wrote a preface, and Peiresc asked for some more poems, to make the book 'more proportionate'. ${ }^{48}$

This first, Parisian collection, which included $3^{\mathrm{I}}$ poems, gives a glimpse of the poetry Barberini, at this stage of his career, wanted posterity to remember him for. An analysis shows it gathered poems dating back as far as the I590's. There is an ode on Pope Clement's happy recovery from one of his periodical bouts of gout, an example of that part of Maffeo's early oeuvre that followed the customary pattern of courtly comments. Customary, also, seem the poems composed to honour the life or work of influential members of the Curia, such as Cardinal Bellarmin, and of personal friends, significantly lauding Maffeo's literary teachers and colleagues such as Cesarini, Chiabrera, Ciampoli and Strozzi. ${ }^{49}$

Although other poems with 'profane' topics are included - about a painting by Guido Reni and about the statue of a golden dragon in the gardens of Cardinal Borghese - most deal with sacred or related sub-

\footnotetext{
45 Bracciolini's letters to Maffeo are in: BAV, BL, Vol. 6459; for the dating of the odes: fols. $98^{\mathrm{r}}$, IO5 $^{\mathrm{r}}$. The last letter: f. Io6 $^{\mathrm{r}}$.

${ }^{46} B A V, B L$, Vol. 6502 , fols. $2^{\mathrm{r}-\mathrm{v}} ; 3^{\mathrm{r}}-4^{\mathrm{r}} ; 7^{\mathrm{r}}$.

47 BAV, BL, Vol. 6502, f. $9^{\text {r }}$, Peiresc to Barberini, December 3, i6r9.

${ }^{48} B A V, B L$, Vol. 6502 , fols. IO $^{\mathrm{r}}-\mathrm{II}^{\mathrm{r}} ; \mathrm{I}^{\mathrm{r}}$, Peiresc to Barberini, April $\mathrm{I} 5$ and September 2, I620.

${ }^{49}$ Ill.mi...Maffaei...card. Barberini...Poemata, o.c., 28, 67, 46, 49, 5I, 53.
} 
jects. There is a series of paraphrases of biblical themes, voiced in such a way that the moral lesson for contemporary life becomes abundantly evident. Also included are the obviously moralistic poems written for his brothers Antonio and Carlo, as well as the ode for young Francesco. Interesting, and probably both politically-motivated and written from sheer horror at the act is the poem on the death of Mary Queen of Scots, described as outright murder ${ }^{50}$ - of course, by removing her Catholic rival, the Protestant Elizabeth had consolidated the Reformation both in England and in Scotland, much to the chagrin of Rome.

However, the Pindaric odes on Saint Louis of France and on Mary Magdalene are singled out for specific comment in the introduction, as is the Ode to San Lorenzo, quite obviously written to counterbalance the poem about the French Crusader king, since the papacy was trying hard to avoid taking sides in the war that had only recently broken out between the Houses of Bourbon and Habsburg. Yet, this introduction does not address politics as such but tells the reader that, at last, Rome has a poet again who writes poetry worthy of the high values held by the Christian religion. While the publisher may have given these texts special prominence because they would appeal to his intended readers - the first two would flatter the French, the last one the Spanish-I yet feel it would be wrong to interpret these texts purely as career-serving political poems, only meant to impress the monarchs of France and Spain: they do reflect the general tone of Maffeo's ideas, and of the pope he was now serving as a cardinal.

\section{The first 'papal' edition}

It was only to be expected that Maffeo's elevation to the papacy in I623 would create a new demand for an edition of his poems. Surprisingly, however, no such edition was published, at least not by the presses traditionally controlled by the popes, i.e. the Vatican Typography and the one attached to the Camera Apostolica. The Parisian publisher eagerly took this golden opportunity and produced a second printing of the $1620-e d i t i o n$. This I623-Paris edition remained the 'standard' one, with its 3 I Latin poems, from which derived the editions published in Cologne, in 1626 , and Vienna, in 1627.

${ }^{50}$ Ill.mi...Maffaei...card. Barberini...Poemata, o.c., 57, 58, 69. 
However, in 1628 , three new editions were published, this time in Italy. The first seems to have copied the Parisian version and was printed in Venice. The second one, enlarged by no less than seventeen poems, originated in Bologna while the third, the most extensive one, came from Codogno. This edition was, in fact, a synthesis of the I623Paris edition and the I628-Bologna one, but added to it were three new texts, bringing the total amount of papal poems now publicly available to $5 \mathrm{I}^{51}$

It took till I63I before the first Roman edition appeared, with the Vatican Press. It had been revised and greatly augmented by Urban himself: the number of poems had been increased to a total of $88 .{ }^{52}$ From various manuscripts I have been able to deduce that Urban was aware that, more than ever, he had to choose his words carefully - e.g. in the Maddalena-poem, the word voluptas is eliminated, while the term pudor is introduced..$^{53}$ This edition was formally presented as a gift from Urban's Collegio Romano. It was a sumptuous production, illustrated with large-scale plates by Bernini and other major artists of the day. More importantly, it had the added benefit of a full metrical apparatus, precisely to facilitate its use in schools - marking this edition as, perhaps, the most propagandistically effective of all of Urban's poetic efforts. For in the same year, a smaller, and therefore supposedly cheaper but yet identical version was published by the press attached to the Apostolic Chamber; this, of course, was the press that usually catered to the people of Rome and of the Papal States and therefore could be instrumental in distributing the book to those teachers who expressed an interest in using it in their classes. Yet, surprisingly, in view of its didactic purpose, this edition shows little systematic composition. The poems are not numbered, nor are they presented thematically. True, the group of paraphrases on the psalms forms the first part, followed by the most important of Urban's various odes, but the rest is an ill-assorted medley of old and new, secular and religious, moralistic and unabashedly political. Why the opportunity to create a truly didactic ensemble was not taken is difficult to fathom.

Though it is obvious the Pope himself took considerable part in the labour involved in producing a meticulously edited definite edition, he

\footnotetext{
51 Castagnetti, o.c., Appendix IV.

${ }^{52}$ Castagnetti, o.c., wrongly counts 83, only.

53 Various manuscripts which contain the Pope's efforts to prepare this edition exist: e.g. $B A V, B L$, Vols. I757; 2027.
} 
certainly did employ others to help him as well. While it is not easy to determine who were involved, I feel one can discern the critical eye of Lucas Holstenius, the erudite famigliare of Urban's nephew Francesco. ${ }^{54}$ This scholar went through the text, correcting points of grammar that, apparently, had slipped from the papal pen, and suggesting that, sometimes, the metre did not correspond with the emphasis of certain words in Greek; perhaps, he even determined the sequence of the poems in the final version. Yet, it seems in all things Urban himself did have the last word..$^{55}$

This first fully authorised edition is of great importance, too, because the Pope himself now chose to publicly explain the principles and purposes underlying his poetry. In a papal brief titled Poesis probis et piis ornata documentis primaevo decori restituenda, that would precede the text of all subsequent Roman editions, he again maintained his earlier stance, viz. that poetry should be restored to its pristine quality, turning its back on pagan themes and images and instead inciting to Christian virtues. Still, sometimes it might be necessary to use classical elements to direct the reader to biblical texts and their messages, or to moral examples. But the Cross, not the Laurel, should be the poet's symbol. Moses and David - especially David, poet, prophet and king - should be his examples. Thus, through poetry, the youth of Italy would return to the ancient values.

Not only was the official Roman edition constantly re-issued, it also was constantly enlarged, as the Pope's poetic vein continued to flow. Indeed, almost each new edition contained additional, mostly Latin poems, their number growing from 88 in 163 I to no less than 152 in I640. ${ }^{56}$ In that year, however, a really new edition came from the presses of the Apostolic Chamber. Its printer-publisher, Andrea Braggiotti, addressing the reader, argued it had become necessary because public demand could not be met, anymore. The new version also boasted a new type.

If one tries to judge the Pope by his own standards, one has to admit that he continued to produce poetry that, at least sometimes, had his moments. In a Christmas poem like Nasceris alme puer, the cold

\footnotetext{
54 See chapters III and VI of this book.

${ }^{55}$ Holste's notes, apparently to be communicated to the Pope through the Maestro di Camera, are in: BAV, BL., Vol. 2077, fols. $224^{\mathrm{r}}$, sqq.

${ }^{56}$ Castagnetti, o.c., wrongly counts I44, only.
} 
and the poverty of the night of Christ's birth are eloquently sketched. The dialogue between Christ and his mother, describing the need for God's son to leave his parent, Mary's will to die with him, and her son's express refusal to allow her to do so have a definite impact. And the emotions evoked by the image of Christ on the Cross in the heart and mind of the believer show the full force of Baroque rhetoric and sentiment.

\section{The editions in Italian}

Though many of Pope Urban's subjects, both within his States and within his Church, commanded a good deal of Latin, many more obviously did not. Probably therefore, from i635 onwards, the Roman editions of Urban's Latin poems mostly were followed by editions of his Italian verses as well - their number rising from 73 to $8 \mathrm{I}$ in the last, I640-edition. While, in I635, these Italian poems are explicitly presented as the Pope's juvenilia, as indicated above the real juvenilia were not included - on the contrary, there are evidently new sonnets denouncing the writing of poetry inspired by impure love. Moreover, the purpose of the poems now published was manifestly didactic, since most are provided with explanatory captions.

All Urban's favourite themes recur: the moral education of the members of his family - various Latin poems for the Pope's brothers and nephews are repeated in their essence, though the wording now is far less complex-, the cult of poverty, expressed in a sonnet on St. Francis, and the prayer-like meditations. ${ }^{57}$

Though Urban may have felt that in producing an Italian edition he might reach a far wider readership, he must have realised that most of his subjects were, in fact, "idioti", illiterate. Yet, while it is to be doubted whether they had any need for the Pope's rather heavy-handed moralising, many teachers may well have read them to their pupils, thus trying to impart the message.

However, there may have been yet another reason for this Italian edition. Dedicated by the editor-publisher, one Ferranti, to Cardinal Francesco Barberini, it also includes a long biographical sketch of the

57 Maffeo Barberini, Poemata (Paris I642), 236; 237; 250; 295 are family sonnets; 294 is the poem on St. Francis. 
Pope's life and actions. Of course, various 'official' histories of the reigning pontifex were produced during Urban's lifetime, but most of these were written in Latin. ${ }^{58}$

In Ferranti's Italian life of Urban, the importance of that earlier Barberini poet, the I4th-century Francesco, author of the famous Documenti d'Amore, is introduced first, obviously to establish the Pope's poetic antecedents. Then Maffeo's poetic purposes are explained. His poetry has three main aims: it wants to help the reader ask forgiveness for his sins, it wants to help him love God and it wants to help him elevate himself to the heavenly principles. The following $4^{0}$ pages are devoted to a detailed sketch of Urban's glorious deeds. Their selection perfectly coincides with the ideas and facts described in the poems presented in this Italian edition.

Urban's material liberality and religious zeal are stressed. From the earliest stages of his career, he took care of the poor and oppressed. No wonder that, when Paul V made him a cardinal, he reportedly had said: 'In the elevation of Maffeo Barberini we have elected a successor to St. Peter.' Meanwhile, Maffeo had shown the proper frame of mind in the construction of the chapel devoted to Mary's Assumption in Sant'Andrea, and in the almost papal way he had acted as Cardinalprotector of the Greek and Oriental colleges and of the Congregation of the Propaganda, the papal ministry for the Spreading of the Faith established in I622. He also had cultivated the learned, and had remained virtuous amidst the intrigues and struggles of the papal court.

And then 'a Swarm of Bees, tinged by the Sun, flew out to announce to the World Honey's happy Age' - a reference to the oft-repeated mythical moment of Maffeo's election to the papacy during the conclave. Now, the world has a pope who is honoured not only by the princes of Europe, but even by the King of Congo and the Emperor of Ethiopia. He has adorned the symbol of his power, the grave of St. Peter, with a mighty canopy. He shows his awareness of the special position in the Church's history of some early benefactors like Constantine, Charlemagne and the Countess Matilda. He takes care of the material and spiritual welfare of his subjects. He has restored the Roman university to its earlier glory, and enlarged the Vatican Library. His concern

58 An important one was: S. Simonini, Silvae Urbanianae, seu Gesta Urbani VIII Pont. Max. Opt. (Antwerp, Plantin's Printing Office, I637). Alas, Urban's official biography commissioned by Cardinal Francesco remained unpublished: BAV, BL, Vols. 4730-4739: A. Nicoletti, Della Vita di Papa Urbano Ottavo e Istoria del Suo Pontificato. 
for the spiritual welfare of the entire world is shown by his missionary policy and the publishing activities of the Propaganda Congregation. Especially the Arab world has his attention, as is shown by the special congregation that convenes to discuss its affairs no less than twice a week. Indeed, his greatest care is the 'sacred enterprise' that he tries to realize with the help of the Christian princes, the war against the Infidel, the theme of several of his poems as well. To that end, too, he constantly promotes peace in the Christian world.

Thus, Ferranti's introductory text would have given an Italian reader who commanded only the vernacular a clear impression of the ideas and actions of the Pope whose poems were before him. Moreover, his edition admirably presents the Pope's poems. A table gives both the Latin and the Italian "incipits", as well as a one-line summary of each poem's content or meaning. The translations are competent and the commentaries themselves are extensive. If, as I assume, the edition was an initiative of Francesco Barberini, he must have been well satisfied by it. Whether read in silence by the children in the Papal States or aloud to a classroom audience, the Pope's biography and the Pope's poems may well have merged into a vision of Christian life lived to the fullthe perfect propaganda for religion and the role of the papacy in it.

\section{Translations}

Although, besides the Italian translation by Ferranti, and the Carducciedition of the Italian version of the Pindaric odes, no translated edition of a significant portion of the Pope's oeuvre ever appeared, many individual poems were translated into various languages.

The single, most numerous group consists of Spanish translations made by Gabriele del Corral which, however, were never published..$^{59}$ As indicated above, several of the odes that specifically dealt with themes dear to the national feelings of France were, almost as a matter of course, translated into French, and printed separately, such as the ode to Mary Magdalene, published in 1618 , and the long Latin poem on Saint Louis, which appeared in French in 1625 .

The fact that the hortatory ode for young Francesco was translated into Greek by the famous Greek scholar Leone Allacci can, I think,

${ }^{59} \mathrm{BAV}, \mathrm{BL}$, Vol. I864. Although I have not been able to trace a published version, in several manuscripts 1627 is mentioned as publication date. 
be explained only because of Urban's and Cardinal Francesco's great interest in, and relations with, the world of the Greek Christians. If so, it served a propagandistic aim. Indeed, when requested to give a judgement, one of the Inquisition's censors wrote that it definitely should be published. ${ }^{60}$

Somewhat more surprisingly, the ode on Louis IX of France was translated into Greek, too, by F. Morel, and published in a separate, bilingual edition as well. This may have been another initiative meant to strengthen the ties with the Christian world of the Near East, more specifically in preparation for the holy war which Urban wanted the monarchs of France - and Spain - to wage against the Infidel, as Saint Louis had done several centuries earlier.

\section{Contemporary explanations and interpretations: the poetics and perils of poetic propaganda}

As the years went by, the number of printed editions of the papal poems increased. Obviously, the two main presses of Rome, that of the Vatican and of the Apostolic Chamber, re-issued their editions, quite probably on express papal orders but also because a genuine demand for them must have sprung up all over the Roman Catholic world. This is borne out by the fact that in 1634 the famous Antwerp printing and publishing firm of Plantin brought out its own version of the Roman collection of I631, which then was reprinted several times. Plantin, or rather his son-in-law Balthasar Moretus had acquired the privilege given to Andrea Bragiotti, the printer-publisher of the Apostolic Chamber. The Antwerp-edition was dedicated to the Pope's nephew, Cardinal Francesco. A portrait of the Pope was included, as well as his Brief introducing the Roman edition.

However, the two most important editions of the Pope's poems were the one devoted to his odes, by Giulio Cesare Capaci, published in Naples in $1633^{61}$ — which offers both a paraphrase and an interpretation, with extensive reference to parallels especially in the Classicsand a more extensive selection made by Henry Dormeuil in I643. They are important precisely because they include commentaries and, more-

${ }^{60}$ BAV, Vat. Lat., Vol. I075, f. 4.

${ }^{61}$ Preparations for this collection can be found in: $B A V, B L$, Vol. 2152, f. $50^{\mathrm{r}}$, sqq.; and $2156, \mathrm{I}^{\mathrm{r}}-26^{\mathrm{v}}$. 
over, because these commentaries connect the corpus of Urban's poetry to his world view, stressing, on the one hand, the links with religion and, hence, with moral life, and, on the other hand, with politics.

No other commentaries were published during Urban's lifetime. The Italian one prepared by Tommaso di Leva for publication in I639 remains in manuscript, only. It seems to stress the didactic value of, especially, a number of the Italian poems, and may have been meant for use in schools. ${ }^{62}$ Also buried in the archives are the comments produced by Magno Perni, a learned theologian from Anagni. He was a prolific author in the field of Canon Law, an even more prolific sermonizer, as well as the biographer of Urban's nephew Antonio junior and the writer of a voluminous guide book for those who visited Rome in the Holy Year $1625 \cdot{ }^{63}$ On top of that he produced a number of comments on Urban's Marian hymns besides extolling Urban's rewritten version of the Breviary, and some of the Pope's moralistic poems ${ }^{64}$ he even manufactured a tract, of more than a Iooo folios, on the Ode hortatoria for Francesco, setting it against the background of some 30 other pertinent papal poems as well as placing it within the wider context of general learning. ${ }^{65}$

By far the most interesting of the unpublished commentaries was the Latin one by Tommaso Campanella (I568-I659). He was a Calabrian friar of the Dominican Order whom, despite or because of his many original ideas - that, basically, favoured an anti-Aristotelian attitude towards the nature and study of the cosmos - many considered a heretic. He had gained Urban's confidence through his alleged ability to influence the course of the stars and, thus, to favourably influence the Pope's future as well. Campanella's text has a significance all its own. ${ }^{66}$

In 1627 , the notorious Calabrese started working on the poems, producing a first set of comments in May i628. Campanella's ideas

62 BAV, BL, Vol. 3653 .

63 BAV, BL, Vol. 3300 .

${ }^{64}$ His texts are in: $B A V, B L$, Vols. $3256,3262,3293,3294,3298$.

$65 B A V, B L$, Vol. 3295 , fols. ${ }^{\mathrm{r}}-\mathrm{II} 84^{\mathrm{v}}$.

66 G. Formichetti, "Campanella a Roma: I "Commentaria" ai Poemata di Urban VIII', in: Studi Romani, 30/3 (I982), 325-339; Idem, ed., Campanella critico letterario. I 'Commentaria' ai Poemata di Urbano VIII (Codex Barberinus Latinus 2037) (Rome I983). Also: L. Bolzoni, 'I Commentari di Campanella ai Poemata di Urbano VIII. Un uso infedele del commento umanistico', in: Rinascimento, Series II, 28 (I988), II3-132, and Idem, 'Il modo di commentare alla fine dell'Umanesimo', in: Annuario della Scuola Normale di Pisa, Classe di Lettere e Filologia, I9/, (1989), 289-31 г. 
at this time, especially as expounded in the introduction, were thoroughly neo-Platonic, specifically as received through the texts of the Florentine philosopher Marsilio Ficino. ${ }^{67}$ For him, the poet was the link between God and the world, between the eternal and the ephemeral. The essence of life is death. Thus, poetry should help the reader to 'interiorise' - Campanella's neologism - this notion, which would bring him to the knowledge of God. Meditation, helped by poetry, would lead not to the experience of nothingness, as Indian philosophers hold, but to the idea that science, profane knowledge, yet though essential to understand creation has its limits; this would be the beginning of true knowledge, of divine wisdom. ${ }^{68}$ Hence, the poet's task was immensely important, a moral obligation of the first order. Poetry should not imitate, as Aristotle demanded, but rather create the verisimilitude of truth. A poet should not be an enchanter, spinning the reader a web of words. Metaphors only kept the reader from recognising the ultimate reality. To bring the reader to the desired truth, poetic 'furor' should be prophetic 'furor' as well. But though 'the aim of poetry is to teach the things as they ideally are', this yet may be done by way of delectation. ${ }^{69}$

In his commentaries, Campanella unabashedly rearranged the Pope's poems to suit his own neo-Platonic ideas. With an avalanche of encyclopaedic learning, he tried to reason away Urban's mitigated use of ancient mythology, his Christian adaptation of Classical allegory, hoping to convince the reader the Pope actually was a Platonist rather than an Aristotelian. Nor was he entirely wrong in interpreting Urban's mind in this vein. Urban had often condemned the use of mythological images, more specifically naming such classical myths as the stories of Phoebus and Daphne, Orpheus and Eurydice, Jupiter and Danae, as the main causes of the decline of poetry's moral power. Consequently, Campanella thought he had found a kindred spirit. Urban, Florentine by birth, well acquainted with neo-Platonism despite his Jesuit, Aristotelian training, was a patron of the new, experimental sciences, a long-time friend of Galilei's and of many Galileans. ${ }^{70}$ Moreover, the

\footnotetext{
67 BAV, BL, Vol. I9I8, f. $4^{\mathrm{v}}$.

68 These notions are expounded in: BAV, BL, Vol. 2037, another volume of Campanella's commentaries, edited by: Formichetti, Campanella critico letterario, o.c.

69 See Campanella's comments in L. Bolzoni's edition of one of the manuscript volumes containing his texts, BAV, BL, Vol. 2048: L. Bolzoni, ed., Tommaso Campanella, Opere Letterarie (Florence I977), 665-889, specifically 786-787, 812, 828, 834.

${ }^{70}$ Urban's contacts with Galilei, from i6i onwards, are thoroughly documented, latest by: P. Redondi, Galileo Eretico (Florence I983).
} 
Pope often referred to the sciences in his poems. Might he not be seeing the world as Campanella saw it? Campanella's world was one in which true knowledge was based on the res instead of the verba. Nature was its source, rather than books claiming the authority of received wisdom. Words existed only to realize things. In his introduction, Campanella claimed that discoveries such as the ones of Columbus and Galilei ranked equal with Holy Scripture as sources of knowledge and interpretation about God's creation. ${ }^{71}$

How did Campanella try to achieve his goal? A single example is illustrative both of his intentions and his methods. Commenting on the poem titled Vera sapientia mortis meditatio, which includes the following passage:

Hospites sumus hic in orbe; non hic

Nobis patria permanens: inani

Laetamur specie boni. ${ }^{72}$

Campanella writes:

Pythagoras, Trismegistus atque Plato animorum immortalitate deprehendentes dissidiumque inter Animos atque Corpora argumentati sunt, Animum non esse proprio in domicilio, sed quasi in carcere, et quoniam non injuste id evenisse Providentia universalis demonstrabat, non nisi culpae aliquando admisse tribuere conati sunt. Et quidem animos immortales esse naturalibus rationibus innotescit, quarum in Atheismo triumphato adduximus multas efficaces. Non esse autem in Patria ex eo planum est, quod Anima corporis terminis vinculisque non tenetur, sed supra Caelum, extra Mundum sine fine extendiunt, intelligendo appetendoque, ut mirum sit quomodo tanta amplitudo in pugillo Cerebri Claudi petuerit. Igitur si non ex corpore dependet, nec ex elementis, quippe que longe transcendit, consequens est, ut extra Patria sibi convenientem, sit solis ergo epicuraeis Animus non peregrinari, sed nasci in corpore, et in corpore vivere, ac mori visum est. At licet Origines Platoni assentiat, haud tamen asserendum propter anterioria peccata animas in corpore detrusas cum id ignorens, vindicta $/ \mathrm{II}^{\mathrm{r}} /$ autem notitia expetat, teste Homero et Aristotele. Sed in agonem et probationem, utque coronentur si legitime certaverint credimus sacris revelationibus in corpore creatas, e corporibus tandem solvendas, iterumque coniungendas, cum comediae universalis finis erit. De quibus alibi. Hic solummodo declaratam volumus naturali argumento ne dum fide teneri, animas humanas in inferiori mundo pererinari. ${ }^{73}$

${ }^{71} B A V, B L$, Vol. I9I8, f. IO $^{\mathrm{r}-\mathrm{v}}$.

72 Maffeo Barberini, Poemata (Paris, I642), I03-I04.

${ }^{73} B A V, B L$, Vol. 2037, f. II $7^{\mathrm{r}-\mathrm{v}}$, I $18^{\mathrm{r}}$. 
Thus, Campanella sought to combine his own explicit poetics ${ }^{74}$ and his philosophical notions with the ideas he wanted to recognise in Urban's poems, even though these were so implicitly voiced as to escape such a fitting interpretation. Actually, as he implied when, at a later stage, he referred to public demand for his edition, he hoped to use his commentaries on Urban's poems as the vehicle to impose his own ideas on the youth of the Papal States and, indeed, of all Christendom. Not surprisingly, his elaborate explications were didactically structured. Each of them began with a preface, giving the general gist of the text; it was followed by a comment on the grammatical and metrical aspects of the poem, 'for the use of minors'; then, the construction proper was analysed; and, last but certainly not least, a philosophical comment 'for the use of adults' was included - by far the longest part of the entire text. Thus, what had been a seemingly simple distich in the hands of Urban might well elicit some nine pages of Campanellian philosophical interpretation. ${ }^{75}$

While Campanella's interpretations may seem excessive, they yet reflected a more general cultural climate that, however, soon was to change.

In the very period in which Campanella was toiling away at his commentaries, on October 31, I629, Lucas Holstenius, the German librarian of the Pope's most powerful nephew, ascended the rostrum in the hall where the Roman Accademia degli Humoristi gathered, to deliver, in the presence of two eminent cardinals, a learned Latin address on Plato and poetry.

According to Holste, the 'divine philosopher' was not an enemy of poetry as some people argued on the basis of a one-sided reading of the Republic. He rather was an enemy of poetry produced for the wrong reasons, of poets who used their words to instil impure thoughts in their readers' minds. Careful scrutiny of the Phaedo and the Timaios, however, revealed that the Prince of the Philosophers strongly believed in that true poetry which showed the "furor divina". The poets who wrote that kind of poetry were no mere authors, they were the priestly intermediaries between God, the greatest poet, who created the soul of the world and the souls of Man, and his creatures, who had to

${ }^{74}$ P. Tuscano, Poetica e poesia di Tommaso Campanella (Milan I969).

${ }^{75}$ E.g. $B A V, B L$., Vol. 2037 , f. $120^{v}$, sqq. The distichon is: "luce fugat tenebra, cera dum vestit ab igne / ac censas faculas, aemula solis apis"; the philosophical part of the commentary is on fols. $122^{\mathrm{v}}-126^{\mathrm{v}}$. 
be liberated from the chains of the flesh to regain their origin, to become one with God again. Poets, real poets helped their readers to use their mind's eye to see the real things, to return into themselves and, through contemplation, reach God, the universe - for 'that which the Platonists term the life according to the spirit, our people call the mystic contemplation of God and things divine' -

praesertim cum de Deo rebusque divinis sine lumine loqui Pythagorae symbolum vetit: et ipse Plato fores poeticas sine furore Musarum adeundas negit, et Socrates de furore amatorio dicturus, non nisi sacro fuore correptus rem adeo arduam aggreditur.

No human power, but God's help alone allowed the reader to escape from the imprisonment of his body, and realize, in himself, the harmony of the cosmos. Poetry, by making man look at the examples of perfection, inducing him to imitate them, was the very instrument to effectuate this process. ${ }^{76}$

Holste was a prudent man, though. Not even once did he allude to the Pope's poems, let alone openly interprete them along the lines of the neo-Platonic vision of poetry's function he had just revealed. And, of course, all this was a proposition, only, he said. His audience would have to judge. Alas, we do not know how the Humoristi reacted. Still, the general drift of Holste's thoughts seems to reflect the intellectual climate of the papal court during the last years of the second decade of the izth century.

In yet another discourse, for which a draft has been preserved, Holste reasoned it did not really matter if one defined Man, with the 'divine Plato', as spirit, only, or, with others, assumed that the body served the spirit: the thing that mattered was that the products of the mind were Man's most essential properties, determining his immortality. ${ }^{77}$ One more text found among Holse's papers, though his authorship is not certain, also reasons along clear neo-Platonic and, moreover, neo-Pythagorean lines. The orator explains to his audience in a Laus Boreae that in Plato's time the tenet of Pythagoras was taught, which held that the souls, before descending into the body, into matter, were particles of the Divine Spirit; they filled the spheres of the cosmos, creating, in their course, the sweet harmony of cosmic music. After

\footnotetext{
${ }^{76} B A V, B L$, Vol. 3072, fols. $6 \mathrm{I}^{\mathrm{r}}-7 \mathrm{I}^{\mathrm{v}}$.

$77 B A V, B L$, Vol. 3072 , fols. $72^{\mathrm{r}}-79^{\mathrm{r}}$ : "De selectioribus compositionibus academicis asservandis ac publicandis dissertatio".
} 
they descended into the body, the harmony was destroyed. Hence, the spirit's, Man's, only wish was to return to its origin, to this harmony. ${ }^{78}$

Meanwhile, when Urban read Campanella's introduction to his poems, he must have been unpleasantly surprised to see that, among other things, the Calabrese philosopher proclaimed the Pope the defender of Galilei's use of the Copernican heliocentric theory - though he himself had been just that, in his own i622-defense of Galilei. In his commentaries, too, Campanella stressed the affinity between Urban's ideas and those of the famous scientist. Thus, in dissecting the poem Vera sapientia mortis meditatio, Campanella elaborates extensively on the distance between the earth and the sun, and on the course of the planets, even citing the proofs offered by the Brahmins of India. ${ }^{79}$

Now, the Inquisition had allowed Galilei's version of heliocentrism as a working hypothesis as early as I620. Indeed, at that time, the then Cardinal Maffeo Barberini had appreciated it as such..$^{80}$ Moreover, he and Galilei had become friends. However, by the end of the I620's, the general mood in at least part of the Church's leading circles had changed, and Galilei's theories were deemed dangerous, though less so for their macrocosmic implications than for their bearing on the nature and structure of matter and its (im)possible mutations - in short, for its bearing on the Church's central tenet of transubstantiation. Soon the Jesuits, who had long been gaining power in the Curia, decided to make Galilei their scapegoat.

For these views about the world and Man as intrinsically material clashed with that of the Church. Consequently, Campanella was asked to rewrite some of his commentaries. In June i628, the rewritten version was ready. More so, in July i629, permission to publish was granted by the papal censor. But publication did not follow.

To what extent Urban's prudent, circumspect nephew, Francesco, felt he should not condone the publication of Urban's poems with Campanella's specific Galilean-Pythagorean interpretation, is arguable.

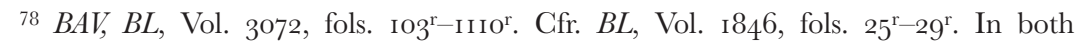
volumes, the authorship of Holste is questioned.

${ }^{79} B A V, B L$, Vol. 2037 , fols. $74^{\mathrm{v}-1} \mathrm{I}^{\mathrm{v}}$.

${ }^{80}$ Barberini to Galilei, August 28, I620, in: A. Favara, ed., Le Opere di Galileo Galilei, XIII. Carteggi (Florence 1903), 48-49. 
Though Campanella's Copernican vision of the cosmos was far less explicit than Galilei's, traditional elements in the Curia deemed these views unwise in view of their policy to strengthen Rome's authority against the world of the Reformation, where many argued that these supposedly Roman ideas were proof of the papacy's perversion. The very fact that Campanella, too, held views of the essentially material nature of the universe and thus threatened the Church's central dogma, sealed the fate of his comments.

The monk, rather foolishly, told one of his friends, the noblemanscholar Federigo Cesi, that the Pope himself had confided to him that the condemnation of Galilei's work 'was not our intent; if it had been our decision, this decree would not have been made'. ${ }^{81} \mathrm{He}$ also tried to frighten the Pontiff, telling him that a number of important Germans, on the brink of conversion through his efforts, had thought better of their decision when the news of Galilei's trial and its implications dawned upon them. This was, probably, counter-productive. The Pope, afraid he himself might fall under suspicion of harbouring Copernican and, worse, Pythagorean and neo-Platonic views, resignedly accepted the fact that the Campanella-edition of his poems was not to be after all. Nevertheless, he may well have regretted it, for though people did, and still do feel Campanella's ideas were, perhaps, rather too farranging, they were all-encompassing, encyclopaedic, and the inclusion of Urban's poems in such a vast worldview may well have tickled the Pope's obvious vanity. At the same time, news of Campanella's hold over the Pope through his astrological experiments ${ }^{22}$ was made public by his enemies, in a cleverly-staged defamation campaign. ${ }^{83}$ Soon, the Pope and Cardinal Barberini helped Campanella to take exile in France.

Meanwhile, however, especially after having read Urban's own introduction to the first Roman, i63I-edition of the poems, Campanella had implored the Pope to allow him to yet publish his commentaries, arguing that all schools, scholars, and, hence, librarians and booksellers

${ }^{81}$ Benedetto Castelli to Galilei, March 16, ı63o, in: Galilei, Opere, XIV (Firenze I904), 87-88.

${ }^{82}$ See chapter VIII of this book.

83 Ibidem. 
were asking for them. ${ }^{84}$ Even though permission was withheld, he continued to work on his text that, however, remained unpublished till the 2oth century.

It is interesting to see how Campanella proposed to achieve his pedagogical end. He had planned to use his contacts with the religious Orders of the Somascs and the Scolopians, whose goal it was to bring culture to the common people through their scuole pie. With the founder of the Scolopians, Father Giuseppe Colasanzio, he shared the ideal of popular education, of a mission that would truly change society ${ }^{85}$ Indeed, he thought bringing wisdom to the people through science, philosophy and art should be the state's, and hence the prince's first aim. In I63o, he addressed a memorandum to Urban stressing the need to introduce proper schooling in the Papal States down to the village level, where reading, writing and religion should be taught, and where the essential findings of science and scholarship, abridged for popular use, should be introduced. Yet, his requests to gain admittance to the Pope were refused. ${ }^{86}$

Some ten years later, in I64I, the Prodromus to Henry Dormeuil's projected three volume, commented edition was published. In the end, only one volume did appear, obviously because of Urban's death in I644. Yet, it is a fascinating, indeed a revealing text that can be combined with the manuscript sections that remain in the archives.

The author was a learned cleric from Liège, a close friend of the influential Lucas Holstenius, ${ }^{87}$ like the latter, he became part of the entourage of Cardinal Francesco, to whom he dedicated his edition. ${ }^{88}$

Dormueil likens Urban's poetics to those of his friend, the Dutch poet-scholar Daniel Heinsius, who holds that, according to Plato, true

${ }^{84} B A V, B L$, Vol. 2048 , f. $40^{\mathrm{r}}$. The commentary Campanella sent is on fols. $42^{\mathrm{r}}-\mathrm{I} 2 \mathrm{I}^{\mathrm{v}}$.

85 There is discussion on this point. It is argued by L. Amabile, Fra' Tommaso Campanella ne' Castelli di Napoli, in Roma ed in Parigi. Narrazione con molti documenti e con opuscoli del Campanella inediti (Naples I887), 304, but somewhat countered by G. Calò, 'Campanella e gli Scolopi. A proposito dell'Apologia delle Scuole Pie', in: Rendiconti della Real Accademia dei Lincei, Scienze Morali, Series VI, XI (I935), 403-427.

86 The text, and the letter, are in: BAV, BL, Vol. 2048. Cfr. L. Firpo, ed., 'Tommaso Campanella, Discorsi universali del governo ecclesiastico', in: L. Firpo, ed., Scritti scelti di Giordano Bruno e Tommaso Campanella (Turin I965), 486-487.

${ }^{87} B A V, B L$, Vol. 2177, fols. 54-105 contains their correspondence, from I629 to I645.

88 Although there is a manuscript dedication to one Joseph d'Adiacet, the promising only son of the count of Castelvillano: BAV, BL, Vol. 2037, I39 . 
philosophy is poetry and true poetry cannot escape philosophizing. Thus, like Campanella, Dormeuil, too, insists that Urban's poetry does not rely on the far less satisfying poetics of Aristotle, least so in its primary function: poetry, as Urban, with Plato, understands it, is a didactic instrument. ${ }^{89}$ Rather naughtily, in view of the Jesuits' known predilection for all thoughts Aristotelian, the Liège-canon stresses the fact that the Societas Iesu itself has adopted the papal poems for its educational purposes, using them precisely because of their happy combination of piety and doctrine. These sacred poems, with their sacred furor so dear to Plato, will help their readers to gain victory over the evils which constantly threaten them in their moral and religious life. ${ }^{90}$

Dormeuil shows a clear understanding of the function of Urban's poetry in its very structure: the poems are presented in a deliberate order, to enhance their impact in the process of reading. It encompasses both the Latin and the Italian compositions, up to the ones most recently published in the official, Roman versions. However, it opens with a great and very interesting poem not published before, in which Urban uses the Vatican basilica as the ideal locus which enables him to poetically sketch the history of the Church and the papacy, and claim the latter's primary role, ending on a rather combative note explaining that the Church, founded on the solid Petrine rock, does not fear the hostile forces of darkness. ${ }^{91}$ Also, Dormeuil's comments are varied, and extensive: they provide details about the persons mentioned as well as about the philosophical and religious background. They explain the arcane allegories and symbols as well.

In short, it is, indeed, a pity that Dormueil's work was not published in its entirety. Not only does it show that Urban's poetic worklike most poetry - could be interpreted in various ways. It also shows that, perhaps, the cultural climate had not changed as drastically as the Galilei-conviction has led both contemporaries and later generations believe. ${ }^{92}$ Indeed, Dormueil's commentaries did not avoid a neo-

$89 B A V, B L$, Vol. 2037, f. I $36^{\text {r }}$ sqq. contains the introductory remarks. On f. I39 ${ }^{\mathrm{r}}$, sqq., Dormueil enters into the resemblance with Plato. Cfr. also: H. Dormeuil, In Maphaei SRE cardinalis Barberini nunc Urbani PP VIII Poemata Henrici Dormali Prodromus (Rome i64I).

90 Dormueil, o.c., $4{ }^{\mathrm{I}}-54$.

91 Dormueil, o.c., 7 osqq.

92 See also Chapter VIII of this book, on the Castelli-case. 
Platonic interpretation but were more circumspect in dealing with those elements in Urban's poems in which Campanella - unwisely and, also, often unwarrantedly - had insisted finding a Pythagorean, materialist vision of the cosmos.

\section{Words and images: illustrating the Pope's poems}

Due to the great length of Urban's pontificate, in the i62os and i63os at least in Rome the 'unity of the visual arts' that is often posed as the essential characteristic of Baroque culture manifested itself both to contemporaries and to posterity in what often seems an excessively strong Barberini vein. In whatever form of visual representation, the family emblem returns, almost smothering the papal capital and the Papal States with the three heraldic insects that may or may not have been bees from the beginning. Indeed, they may have been wasps, originally - it is difficult to determine their exact nature from the evidence of seals and carved armorials predating the Barberini's Roman ascent under the aegis of Maffeo. But whatever their origin, from the beginning of the 17 th century, Barberini bees were given pride of place.

The origins of the bee as an emblematic sign have been discussed ad nauseam. ${ }^{93}$ I will not add my own shilling to this already over heavy scholarly sack, but for noting two points that seem to have escaped many researchers. In the I6th and I7th century, the Jesuits adapted an age-long, secular tradition of bee emblems to their own purposes, giving them a specific religious and moral-philosophical slant. ${ }^{94}$ Their imagery centred around the Virgin Mary, the Mother of the Lord, the epitome of chastity who was likened to the bee, her womb to the hive. Honey could thus become the dew of heaven, Divine Wisdom, that should inspire princes and rulers both temporal and spiritualmost of all, of course, that perfect fusion of the two, the pope, the

93 Still important the survey by: W. Robert-Tornow, De Apium Mellisque apud Veteres Significatione et Symbolica et Mythologica (Berlin I893).

${ }_{94}$ See: R. Dimler, 'The Bee-topos in the Jesuit Emblem Book: Themes and Contrast', in: A. Adams, A.J. Harper, eds., The Emblem in Renaissance and Baroque Europe. Tradition and Variety (Leiden I992), 229-246. Dimler, however, fails to even mention the Barberini case. 
keeper of the sacra monarchia. ${ }^{95}$ What with Urban's early links with the Jesuit ${ }^{96}$ as well as his great love for the Immaculate Virgin who was, indeed, worthy to have generated Christ, Divine Wisdom incarnate, the origin of the profusion of bees that now began to swarm over Rome seems clear: its manifold possibilities for emblematical propaganda simply had to be exploited.

Another point that is often overlooked is the extremely fortunate circumstance that both in Maffeo's own generation and in the next there were, indeed, three Roman Barberini brothers. ${ }^{97}$ This gave visual propaganda an extra edge in terms of signification. Indeed, even in the illustrations that adorned the various editions of the Pope's poems it could be used to good effect, not least because the poet himself composed several poems that either were addressed to the three Barberini brothers or the three nephews, or to other exemplary threesomes who could be taken as their ideological or moral predecessors.

The first illustrated edition of Urban's poems was the Roman one of I63I. Its frontispiece was engraved by the French artist Claude Mellan (I598-I688) after a design by Gianlorenzo Bernini, showing David - obviously to link the poet-king with the poet-pope - wrestling with a lion, his harp thrown aground. The I634-edition produced in Antwerp by Balthasar Moretus also has a magnificent though more problematic frontispiece. The engraving is based on a design by Peter Paul Rubens who obviously was paraphrasing Bernini. But whereas Bernini, and Mellan, showed a youthful, beardless David who, having laid aside his lyre, is at grips with a lion whose mouth he opens to allow a swarm of bees to escape, Rubens's engraving shows an older man, probably Samson, who, returning to the carcass of the lion which he has killed, finds a swarm of bees filling its mouth already. Yet, in Rubens's design, too, the lyre is prominently present, although it was not amongst Samson's usual attributes.

Should we assume that the painter meant the readers to think of physical strength, or rather the force of arms - which the Pope particularly needed in these years of international war-as being the more

\footnotetext{
${ }^{95}$ Cfr. A. Buoncompagni, La Sacra Monarchia. Panegirico della coronatione di N. Signore Papa Urbano Ottavo (Rome I623).

${ }_{96}$ Cfr. M. Fumaroli, 'Cicero Pontifex Romanus: la tradition rhétorique du Collège Romain et les principes inspirateurs du mécénat des Barberini', in: Mélanges de l'Ecole Francaise de Rome (Moyen Age et Temps Modernes), 9o (1978), 797-835.

97 Obviously, the three Barberini who had moved to Rome considered themselves a unity, despite the fact that other brothers remained behind in Florence.
} 
effective when combined with the sweeter forces of Apollo, or rather David, who sang the praises of God, just as the Pope, through his poems, enticed his audience to act as peacefully as the Church prescribed and thus in the end would eliminate the need of force? Perhaps, but one may think of yet another identification: one of the cartoons designed by Pietro da Cortona for a series of Barberini tapestries illustrating the Life of Constantine seems to have shown the emperor struggling with a lion, too. ${ }^{98}$ Obviously, the relationship between the Pope and the first Christian emperor was continually stressed in all kinds of papal propaganda manifestations because the legal basis of Rome's sovereignty over the Papal States was precisely the so-called Donation of Constantine, a document still widely cited though its falsehood had been established already. The table of contents is followed by an engraved rendering of Bernini's portrait of Urban. Another plate shows three bees in the rather strange act of ploughing. The text says: 'from an ancient gem', and explains, rather cryptically: 'highest rule, sown fields of cultivated land, production of honey: these three symbolize these greater things'. And indeed, amongst Cardinal Francesco's prized possessions was an antique gem cut with this image. Its source seems to be a passage from the fourth book of Virgil's Georgics; the caption symbolically states the fact that precisely because the three Barberini nephews together hold the three main offices of the "Patrimonium Petri" and the "Ecclesia Romana" - chamberlain, chancellor and general - they guarantee the prosperity of State and Church.

In a way, the most important illustrated collection was to have been the three-volume Dormeuil-edition of I643. The one volume published is absolutely covered with bees, either in swarms or, more often, in the ubiquitous threesomes. To judge by the many captions, Dormalius was of the opinion that bees, especially as a triad, could represent well nigh everything positive: they link Heaven to Earth, bring Peace, accompany the Muses and, of course, symbolize the Barberini who have restored Rome's ancient power as an arbiter in Christendom. ${ }^{99}$ Moreover, the book is riddled with other emblems as well. Most of these also were part of the regular Barberini repertoire as codified, already in 1623 , by G. Ferro in his Teatro d'Imprese, printed in Venice. Whereas according to Ferro the bee could stand for resurrection and apotheosis, resulting in immortality through virtue, the sun could be

98 Lavin, Seventeenth-century documents and Inventories of Art, o.c., 227.

99 Dormalius, o.c., I73. 
used to illustrate either Divine Wisdom, or Christ's resurrection; ${ }^{100}$ the lion would symbolize strength; the laurel, often shown as a tree, represented virtue. ${ }^{101}$ Obviously, these imprese lent themselves to endless combination and, hence, to near-endless speculation. Of course, one may well wonder whether the often intricate meanings read into these allegories and emblems by present-day scholars really were understood by any but the most astute contemporary observers. ${ }^{102}$

\section{Words and sounds: the music of papal poetry}

Music was an integral part of the way Baroque culture sought to express itself. Various members of the Barberini family were true music lovers: the costly and gigantic opera house-it held no less than threethousand seats - constructed alongside the Barberini Palace was no mere extravaganza of cultural propaganda, and Barberini patronage of composers and other musicians went far beyond the dictates of court culture. Daily routine both in Urban's rather sober household at the Vatican and in his nephews' far more sumptuous establishments in the Palazzo della Cancelleria-Francesco's official residence - and the family palaces at the Via dei Giubbonari and, later, at Quattro Fontane was spiced with numerous moments of musical entertainment.

One of the Pope's courtiers, Giulio Rospigliosi, provided the libretti for a series of operas that were staged for all kinds of festive occasions, such as when the imperial ambassador Prince Hans Ulrich von Eckemberg visited Rome in 1632. In one of the rooms of the new Barberini palace, a special performance was given of the recently completed drama "Sant'Alessio". ${ }^{103}$ Set to music by Stefano Landi, it was one of the many texts that, through Rospigliosi's pen, reflected the specific ideas of Pope Urban on the didactic and moralistic function of vocal music, too: musical drama should not wallow in pagan heroism or arcane mythology, but rather stress the need to leave the wicked world in pursuit of Christian virtues. Such tragic figures as Saint Alexis proved the proper protagonists of these elaborately staged pieces. ${ }^{104}$

\footnotetext{
100 According to Scott, o.c., they even represented the eternal rule of the Barberini.

101 Ferro, o.c., $65 \mathrm{I}-654$.

102 The visual side of Barberini propaganda is treated with great insight by: Scott, o.c., I93-197.

103 The first (CD-)recording of the Sant'Alessio has been produced in 1995 .

104 M. Murata, Operas for the Papal Court, I63I-I668 (Chicago 1975), 2-37, as well as: Fr.
} 
A pope who attached such importance to the relationship between word and music for the greater clarity of the religious message could not but show an interest in the principal instrument that was used in this context, the poetical and musical setting of the Breviarium et Hymniarium Romanum, used all over the Catholic world. Thus we find Urban pressing for the completion and final revision of the Breviary and the Hymnal - that had been under way since the pontificate of Clement VIII - according to Tridentine tenets. To that end, he had written many hymn-texts himself, both for the feast of Easter, and to celebrate the feasts of the Virgin Mary, whose role he particularly stressed. ${ }^{105} \mathrm{He}$ also appointed himself to a committee amongst whose other members he selected four learned and poetically competent Jesuits, viz. Famiano Strada, Tarquinio Galluzzi, both professors of rhetoric at the Collegio Romano, Geronimo Petrucci, and the prefect of the Collegio Germanico, Carlo Sarbiewski, the latter a very able Latin poet in his own right. ${ }^{106}$

In March I629, their proposals were put before the Congregation of Rites ${ }^{107}$ and, of course, accepted. In the same year, the Hymnal was printed, in three different formats. ${ }^{108}$ The revision of the Breviary took another three years. Incorporating the Hymnal, it was published in I63I. Urban expressed his joy over the completion of this enterprise, first contemplated by Sixtus V in I588, in the Bull Divinam Psalmodiam of January i63i. In it, he explained the need to present the faithful with a text that could easily be sung and, thus, would facilitate their emotional contemplation of God; moreover, it had been expurgated of the many mistakes that had crept into it over the past centuries.

For easy use, the revisers had divided the hymns in five groups. The first, including such venerable, ancient texts as the Te Deum, the Ave Maris Stella and the Victimae Paschali Laudes, had been left intact. A sec-

\footnotetext{
Hammond, Music and Spectacle in baroque Rome. Barberini Patronage under Urban VIII (New Haven I994), 20I-202; 209-2I2. See, also, Chapter IV of this book.

${ }^{105}$ Cfr. BAV, BL, Vols. 3256, 3264, 3296, 3298, 3299, 3305: the manuscript texts of a series of commentaries and explanations by Magno Perni to Urban's hymns and the new Breviary and Hymnal.

${ }^{106}$ J. Warszawski, Dramat Rzymski (Rome I984); J. IJsewijn, 'Scrittori Latini Romani dal Barocco al Neoclassicismo', in: Studi Romani, 36 (I988), 229-249.

107 BAV, BL, Vols. $76 \mathrm{I}-763$ contain the documentation.

108 Hymni Breviarii Romani Sanctiss. Domini Nostri Urbani VIII Iussu, et Sacrae Rituum Congregationis Approbatione emendati, et editi (Rome i629).
} 
ond group had been corrected on the basis of a thorough study of the manuscript material, with the aim to best reflect the authors' intents. A third group of obscure, anonymous hymns had been altered somewhat more drastically, as had a fourth group in which the metre did not seem to function properly. A fifth group, of texts for the Eucharist attributed to St. Thomas Aquinas, had not been tampered with; though they might be defective in elegance, their majesty and the use the Church had made of them proclaimed them inviolable. ${ }^{109}$ Interestingly, however, Urban, besides correcting some of the ancient texts, also introduced new ones, precisely ones composed by him. Judging the Pope's policy somewhat romantically and anachronistically, some of his later critics have accused him of 'increasing the Latinity, but decreasing the piety' of the hymns. ${ }^{110}$ Yet these 'Ciceronianised' hymns were retained for more than three hundred years, till the second Vatican Council, not entirely necessary, decided to eliminate many of Urban's emendations.

Meanwhile, the new texts had to be musically adapted to the polyphony of Giovanni Pierluigi da Palestrina, the i6th-century composer whose mostly unaccompanied, so-called "stile antico" continued to reign supreme in the Sistine Chapel long after his death. It was a laborious process that took more than ten years. In i644, the revision, by Gregorio Allegri (1582-1652) - whose famous "Miserere" for Maundy Thursday was probably heard by Pope Urban as well-, was published in Antwerp, the Netherlands being the foremost musical publishers of Europe. ${ }^{111}$ It contained such interesting settings as the Mass "Vidi turbam magnam". In the mean time, Filippo Vitali (c. I590-I653), a singer in the Papal Chapel and, moreover, Cardinal Francesco Barberini's acknowledged "virtuoso", well-known for his madrigals, already had provided an alternative, polyphonic setting for Urban's hymns, only, which was published in $1636 .{ }^{112}$

Not surprisingly, Urban was well pleased when his favourite musicians, employed either by himself or by his relatives, decided to set his poems to music.

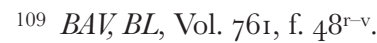

110 A. Springhetti, 'Urbanus VIII P.M. poeta latinus et hymnorum Breviarii emendator', in: Archivum Historiae Pontificiae, 6 (I968), I63-19o.

111 Hymni Sacri in Breviario Romano (Antwerp r644).

112 Filippo Vitali, Hymni Urbani VIII ... jussu editi (Rome I636). 
Already in I624, Johann Kapsberger (c. I580-I65I), who later was employed by Cardinal Antonio Barberini, the Younger, and whose son served Cardinal Francesco, published a first volume of musical settings to Urban's poems under the title Poemata et Carmina - obviously an enterprise meant to curry favour with the new pope, of whose cultural patronage all artists held the highest hopes. After a beautiful frontispiece cleverly combining the Barberini emblems in a surround for the Muses offering their products - music and text - to a female figure, the allegorical representation of the Church, there follows a fulsome introduction by the composer. Kapsberger certainly knew what the Pope would like to hear. All Europe now would be able to see that in Rome the arts flourished again. He had made a selection from the papal Pindaric odes, concentrating on those poems that dealt with the triumphs of the saints or presented stories of human intellect spreading the word of Divine Wisdom. There was to be no 'indecent music', only that which would serve the mind's reflection. All in all, Kapsberger's selection comprised ten pieces, amongst which an elaborate setting of the Paraphrasis in canticum trium puerorum ${ }^{113}$ - perhaps because it could be construed to refer to the three papal nephews, Francesco, young Antonio and Taddeo. Rome's foremost musical theorist, the severe critic Giambattista Doni, declared Kapsberger's compositions to be excellent, which, in his discourse, meant in the ancient mode: the music followed the modulation of the words, without adding all kind of florid embellishments that only served the affective needs of the ear. Doni himself asked the composer Pedro de Heredia to provide the music for the text of Urban's sonnet Passa la vita; Heredia obliged in Doni's vein, composing the song in the two ancient "modoi" of Dorian and Phrygian.

This set the tone. Kapsberger, while also setting to music texts by Urban's secretary, the poet Ciampoli, as in the beautiful song I Pastori di Bettelemme, in 1633 followed up his first volume of papal music with a second one, that seems to be lost. In the meantime, in i63i he had published a series of, admittedly, rather dull Missae Urbanae, ${ }^{114}$ as well as, in 1632 , a setting of Urban's Litaniae deiparae Virginis, ${ }^{115}$ presumably because he knew the Pope's ideas about the Virgin's special position as the Immaculate One. The three masses, for four, five and eight voices

\footnotetext{
113 Kapsberger, o.c., 25-32.

$114 B A V, B L, \mathrm{BN}$ XIII, I67-176.

$115 B A V, B L$, BN XIII, 62-I66.
} 
respectively, either with organ or continuo, were after the Tridentine manner, without counterpoint. They often were sung in the Pope's presence. ${ }^{116}$

Domenico Mazzocchi (I592-I665), famous for his vocal chamber music, in I638 published a collection of a capella-songs under the title Poemata, ${ }^{117}$ all set to Urban's texts. Like Kapsberger's, they comprised ten pieces, for I, 2, 3 and 6 voices - the last one, significantly, again the Paraphrasis in canticum trium puerorum. Some of the settings effectively use the dialogue-like character of Urban's texts to provide expressive musical renderings of the emotions involved.

In the same year, another collection of Mazzocchi's songs appeared, the Dialoghi e Sonnetti posti in musica, ${ }^{118}$ partly based on the Pope's poems as well. ${ }^{119}$ Rightly famous became the setting of the Lagrime amare all' anima che langue, as voiced by Mary Magdalene, one of the Pope's favourite saints. In Mazzocchi's I640-collection of Musiche sacre e morali, Urban's poetry was used again. ${ }^{120}$ In i64I, he published a collection featuring Urban's elegy Praetereunt anni, coupled to a dialogue from Virgil's Aeneid. ${ }^{121}$

We do not know if all this Urbanian music was performed regularly. However, we do know that music was not only a favourite pastime in the various Barberini-households but also an integral part of the evening meetings of the various Roman academies, such as the Academia Basiliense, the Accademia degli Deziosi, and the ones of the Lincei and the Umoristi, to which most of the papal courtiers belonged. Especially the Basiliense, of which Doni was secretary, was famous for its disputes on musical theory; there, the execution of a piece like Heredia's would have served to illustrate Doni's complex views.

116 Hammond, o.c., I67.

$117 B A V, B L$, BN XIII, 4 .

$118 B A V, B L$, BN XIII, 7. I have been unable to consult the only modern editionknown to me - of any of Urban's poems-set-to-music, R.E. Englehart's unpublished Ph.D.-thesis defended at Kent State University in 1987: Domenico Mazzocchi's 'Dialoghi e Sonetti' and 'Madrigali a Cinque Voci' (I638): A modern edition with biographical commentary and new archival documents. Though F. Noske, Saints and Sinners. The Latin Musical Dialogue in the Seventeenth Century (Oxford I992) deals with Mazzocchi's oeuvre quite extensively, he does not analyze any of his Urbanian settings.

119 A reprint was published: Bologna, I969.

${ }^{120} B A V, B L$, BN XIII, 20I. A reprint was published: Bologna, I988.

121 D. Mazzocchi, Praetereunt anni. Elogia Urbani papae VIII, et Aeolus, dialogus ex libro primo Aeneidos (Rome I64I). 


\section{Conclusion: "delectare et docere"}

Many popes have furthered the cause of poetry, without ever materially contributing to the genre. ${ }^{122}$ Maffeo Barberini, however, was a poet before he could even think to aspire after the papacy. As pope, he continued to be a poet. Rather than, only, expressing a personal aesthetic in his poetry, he used it as the powerful means it was precisely to propagate his deepest convictions and feelings. He felt that, poetry being, in itself, amoral, its obvious propagandistic, for emotional effect could be justified only by giving it a supremely moral content. Not surprisingly, the Poet-Pope's contemporaries more often than not were effusive in their sycophantic praise. Nor have later generations been entirely unkind. ${ }^{123}$ Yet, this is not the place to pass judgement on the quality of Maffeo Barberini's poetry. Indeed, I feel unable to give such an aesthetic assessment. Much more important, and the very reason why such an assessment nowadays is indeed difficult, is the question of the poems' significance in contemporary culture, a culture essentially religious.

To gauge the role Urban's poems played, a number of facts can be adduced. The first one is that the 'duodecimo', or 'pocket book'Bologna edition of I629 specifically announces itself as produced for educational purposes. ${ }^{124}$ Moreover, the Jesuit teachers of the influential Collegio Romano, the educational cradle not only of generations of Roman nobles but also of a host of papal civil servants originating from all over Italy and of many foreign students as well, did prescribe the Pope's poems to their pupils. ${ }^{125}$ In fact, they themselves were responsible for the luxury edition brought out by the Vatican Press in I63I. Was it, perhaps, meant to placate the Pope, whith whom the Society of Jesus was constantly battling over issues of religious dogma and policy? As indicated above, in it, each poem is introduced by a commentary indicating, also, the metre that should be used.

The Dillingen-editions of Urban's poems, produced in I640 and I643, were Jesuit enterprises, too, and, presumably, meant for educational purposes as well. Not surprisingly, in his letters to the editors, Fathers Forner, Ilsing and Wangenreck, Urban expressed his gratification. ${ }^{126}$

122 Gfr. G. Travaglini, I papi cultori della poesia (Lanciano I887).

123 According to Costanzo, o.c., I8-I9, the Latin poems at least were favourably judged till well into the I8th century.

${ }_{124}$ Maffaei...poemata...curante Academia Noctis (Bologna i629), "Lectoribus", 3.

125 According to Dormalius, o.c., 42, and J.N. Erythraeus, Pinacotheca Imaginum illustrium virorum Vol. II (Cologne I645), I53.

126 Springhetti, a.c., I82. 
Some may argue that Urban's poems would not have found a publisher at all if not for blatantly opportunistic reasons. Actually, I disagree. Rather, it seems to me the poems of Maffeo Barberini should be seen - and indeed were seen by his contemporaries - as an valid effort to forge a much-needed synthesis between the eloquentia profana and the eloquentia sacra, between Humanist and Christian culture, of which the Jesuits were the first advocates. They sought to use - and reconcilepagan rhetoric and poetry with the aims of Faith as formulated by the Council of Trent. ${ }^{127}$ Once elected to the papacy, Urban must have deeply felt the need to strengthen this policy. Within the broad context of a renovatio litterarum et artium that should restore Rome's position at least as the moral capital of the Christian world, the Church also should try to re-tune its language, Latin, to adapt it to the need of convincing as wide an audience as possible of its fundamental truths. NeoCiceronian rhetoric was considered the proper means to this cause. Hence, poets who were willing to be guided and inspired by the papal example were given important functions at the papal court: as indicated above, Virginio Cesarini was made maestro di camera, Giovanni Ciampoli became secretary of the Papal Briefs. Young Cardinal Francesco appointed the famous rhetorician Agostino Mascardi (I59I-I640), who had proven his skills in a verbal recreation of the visual pomp surrounding Urban's formal acceptance of the governance of Rome, ${ }^{128}$ and who knew how to play to people's emotions, to the prestigious chair of rhetoric at the Sapienza. ${ }^{129}$

Thus, Rome became more than ever a theatre where all audio-visual means were used to create spectacles that would convince precisely because of the combination of docere and delectare - the Jesuit ideal also voiced by that influential scholar, Father Bernardino Steffonio, S.J., who had provided the iconographic program of the earliest Barberini 'theatre', the family chapel. ${ }^{130}$

127 For this: M. Fumaroli, L'Age de l'Eloquence. Rhétorique et "res literaria" de la Renaissance au seuil de l'époque classique (Geneva i980).

128 A. Mascardi, Le pompe del Campidoglio per la S. di N.S. Urbano VIII quando pigliò il possesso (Rome s.d.).

${ }^{129}$ In I639, Mascardi published, in Paris, his important theoretical works: Ethicae Prolusiones, dedicated to Cardinal Antonio, and Romanae Dissertationes de affectibus...animi earumque characteribus, dedicated to Cardinal Francesco Barberini.

130 See the Prologue to this book. Cfr. also: M. Fumaroli, 'Theatre, humanisme et Contre-Reforme a Rome (I597-I642): l'oeuvre du P. Bernardo Stefonio et son influence', in: Bulletin de l'Association Guillaume Budé, XXXIII (1974), 397-412. 
The new Barberini Palace became another such theatre, where the pictorial decoration of the State Rooms proclaimed the rightful rule of Urban and of his Barberini relatives as messengers and intermediaries of Divine Wisdom. ${ }^{131}$ Though not, strictly speaking, a direct illustration of Urban's poetry, two of the main items of the decoration of the new Barberini Palace can be seen as a visual commentary on his life and achievements, and, more specifically, of the ideals underlying his actions, ideals that were expressed verbally in his poems and, materially, in his general cultural policy.

The new palace's grand salone was given a sumptuous ceiling fresco by Pietro da Cortona. ${ }^{132}$ Significantly, the original suggestion to make Jupiter the centre of this fresco - as had, of course, been a long-standing Renaissance tradition - was severely amended by Urban. Holding to his poetic tenet that art should provide a moral message through moral images, he replaced this pagan god with the allegory of Divine Providence. It is this heavenly power that overthrows the giants, the symbols of the various heresies which threaten the foundations of Faith and of the Church.

To help him achieve the desired result, Cortona was asked to also work from a poem published in I628 by one of Urban's court poets, Francesco Bracciolini. In this text, titled L'elettione di Urbano Papa VIII, the Pope was exalted as the man chosen by Divine Wisdom to represent heaven on earth, as the leader of Christ's Church. Hence, in the fresco, Divine Justice crowns the Barberini arms, Religion attaches to them the papal keys, Rome raises the three-tiered crown above them and a cherub descends to surround them with the laurel wreath of the archetypal poet, Apollo. Elsewhere in the palace, the painter Andrea Camassei did depict Urban himself as (the new) Apollo.

The second representation of Barberini-papal ideology in the new palace seems to have been even more closely linked to its most vocal expression, Urban's poetry. Between I630 and I64I, two sets of tapestries were created for the walls of the great saloon, one of them telling the story of Constantine the Great and of his relics in Rome, which, of course, provided the foundation for the temporal power of the

131 See, of course, Scott, o.c., though I would rather stress the importance of the message of Divine Wisdom using the Barberini family as a vehicle to reach out to Mankind, than that family's right to rule.

132 The most exhaustive treatment in: Scott, o.c., passim. 
papacy, ${ }^{133}$ the other representing the Life of Christ, including, amongst other topics, the favourite Urban theme of the life of the Virgin, and of the donation of the keys, which secured the popes' spiritual authority; significantly, one of the tapestries showed a map of the Holy Land, telling, thus, of the ancient papal dream of recapturing the places most sacred to the Christian world.

A third series of ten tapestries was based on iconographical suggestions originally made by Francesco Ubaldini, ${ }^{134}$ though they were woven after Urban's death. It gave the major scenes of the Pope's lifeincidentally or not coinciding with the biography of Urban as presented in the introduction to the 1635 -Italian edition of his poems by Ferranti as, for example, Maffeo receiving the doctorate in Pisa, Maffeo regulating the flow of Lake Trasimene, and Maffeo-Urban defending Rome from the plague, et cetera. More interestingly, several of this last series of Barberini tapestries can be linked to the two great politically programmatic poems composed by Urban during the last years of his pontificate, the one defending the origins of the dual power of the papacy, viz. over the Universal Church and over the Papal States, and the other calling upon the Christian princes to unite against the common enemy, Islam. ${ }^{135}$

However, there were to have been four additional scenes. It is precisely these, remaining unwoven, that would have glorified the Pope's cultural activities: his patronage of the virtuosi of his time, the virtue he acquired through his support of the arts and sciences, specifically the art of rhetoric and the foundation of several institutes of learning. ${ }^{136}$

The great library hall of the new palace, open to the public through a separate entrance, was in itself a veritable theatre, dedicated to the Logos, where knowledge was ordered according to the strict laws dictated by its service to Faith: of course, bibles in all languages were given pride of place. ${ }^{137}$ Soon, the library was famous, one of the sights of

${ }^{133}$ D. Du Bon, Tapestries from the Samuel H. Kress Collection at the Philadelphia Museum of Art: the History of Constantine the Great (Aylesbury I964).

134 Thus far, I have followed the analysis and interpretation offered by Scott, o.c., I86I89. Cfr. also: I. Faldi, I cartoni per gli arazzi Barberini della serie di Urbano VIII (Rome I967); U. Barberini, 'Gli arazzi e i cartoni della serie 'Vita di Urbano VIII' dell'arazzeria Barberini', in: Bollettino d'Arte, 53 (I968), 92-Ioo.

135 The poems titled Primordia and Adhortatio ad Bellum Sacrum. See: Poesie Latine (Rome I642), 34-48, II I-I26.

${ }^{136}$ The list of themes is given in: $B A V, A B$, Indice II, 2693.

137 For a contemporary description, see: G.Teti, Aedes Barberini ad Quirinalem (Rome I64I). 
I7th-century Rome, praised in guidebooks and poems alike. ${ }^{138}$ No wonder that, though this was hardly customary, Cardinal Francesco, the most important Barberini connected with the palace despite the fact that he actually spent most of his time in the Cancelleria, used the room for some of his more politically spectacular audiences. ${ }^{139}$ It was, indeed, a room that made a statement. In it, the statue of its founder, Pope Urban, was flanked by Mercury and Minerva, which seemed to proclaim that in this Pope these two allegorical figures found their ideal synthesis: pagan Eloquentia should, thus, lead to Christian Sapientia, bring man to Divine Wisdom. It was the message Urban had been proclaiming in his poems. It was the message that the cultural policy of his papacy proclaimed in many of its manifestations.

So perhaps there was something of a poetic program underlying Barberini propaganda and politics after all. Yet it was not a program that relied on the literalness of words, alone. On the contrary, most of Maffeo's poems, in referring to a universe ruled by abstract ethical and indeed moral-religious principles, could only do so by using metaphors and symbolic concepts, relying on the power of the verbal and the visual image as much as on the literal meaning of words. Precisely because the culture of the Baroque period was not, yet, a 'literal' culture only, it resulted in a unity not only of the arts but of all aspects of life - at least in the vision of the pope who dominated these decades.

138 E.g. A. Florente, 'In Bibliothecam Francesci card. Barberini', in: Poemata septem illustrium virorum (Antwerp i660).

${ }^{139}$ Gigli, o.c., June I642. 


\section{APPENDIX \\ GHRONOLOGIGAL LIST OF THE MAIN (COLLECTED) EDITIONS OF THE POEMS OF MAFFEO BARBERINI ${ }^{140}$}

Illustrissimi et reverendissimi Maffaei Sacrae Romanae Ecclesiae cardinalis Barberini... Poemata (Paris, A. Stephane, I620, though the privilege is dated I62I) (in 4.o). [3 I poems]

Ill.mi et rev.mi Maffaei SRE card. Barberini...nunc Urbani papae VIII poemata. Editio secunda (Paris, A. Stephane, I623) (in 4.0). [3I poems]

(Reprinted: Cologne, I626)

(Reprinted: Vienna i627)

Sancti Domini Nostri Urbani VIII...poemata

(Parma i624). [32 poems]

SDN Urbani VIII...poemata

(Vienna i627) [33 poems]

Ill. et rever. Maffaei...Barberini nunc Urbani VIII Poemata

(Venice i628) (in 8.o) [33 poems]

Maffaei card. Barberini, nunc Urbani VIII...poemata. Editio caeterorum locupletissima, curante Academia Noctis

(Bologna i628) (in I2.o) [46 poems]

Maphaei SRE card. Barberini, nunc Urbani PP VIII Poemata

(Rome, Vatican Printing Office, I63i) (in 4.0) [83 poems]

Maphaei SRE card. Barberini, nunc Urbani PP VIII Poemata

(Rome, Vatican Printing Office, I63i) (in 8.o)

Maphaei SRE card. Barberini, nunc Urbani PP VIII Poemata

(Rome, Printing Office of the Apostolic Chamber, A. Bragiotti, I63i) [83 poems].

(Reprinted: Antwerp I634 [94 poems])

(Reprinted: Rome I635 [IO7 poems], I637 [I2I poems], I638 [I29 poems], I640 [I44 poems])

(Reprinted: Dillingen I640 [I44 poems], I643 [I44 poems])

140 My survey, based on my own research, though certainly not as extensive as the various Castagnetti lists, ut supra note 309, differs from them in a few respects, probably due to differing bibliographical data. 
Poesie toscane del card. Maffeo Barberini, hoggi papa Urbano Ottavo

(Rome, Printing Office of the Apostolic Chamber, I635) (in I2.o)

(Reprinted: Rome I637 [in 4.o], I638 [in 4.o], I640 [in I2.o])

(Reprinted: Paris, I635 [in I2.o])

In Odas eminentissimi cardinalis olim Barberini nunc Sanctissimi Papis Urbano VIII Iulii Caesaris Capacii notae

(Naples i633, reprinted i635) [N.B.: only the first part was published]

Maphaei SRE card. Barberini nunc Urbani papae VIII poemata. Poesie toscane del card. Maffeo Barberini hoggi papa Urbano Ottavo

(Paris, Royal Printing Office, I642) (in 4.o).

Poesie latine del card. Maffeo Barberini hoggi papa Urbano ottavo tradotte in verse sciolte da Gio.Francesco Ferranti

(Rome I642)

Maphaei SRE card. Barberini, nunc Urbani PP VIII Poemata. Henricus Dormalius explicabat (Rome, L.Grignani, I643) (in 4.0)

[N.B.: only one volume of the projected three was published].

Ode alla pindarica della Santità di Nostro Signore Urbano VII, trasportate nella rima toscana da Francesco Carducci

(Rome I644).

Maphaei SRE card. Barberini, nunc Urbani PP VIII Poemata. Praemissis quibusdam de vita auctoris et annotationibus adjectis. Edidit Josephus Brown... Oxoniii

(Oxford I726). 